\title{
Cardiovascular issues in older adults
}

By: Leslie L. Davis

Davis, LL. (2014). Cardiovascular issues in older adults. Critical Care Nursing Clinics of North America. Special Edition: Age Related Complications of Critical Illness. 26 (1): 61-89.

***@ Elsevier. Reprinted with permission. No further reproduction is authorized without written permission from Elsevier. This version of the document is not the version of record. Figures and/or pictures may be missing from this format of the document. $* * *$

Made available courtesy of Elsevier: https://doi.org/10.1016/i.ccell.2013.10.004

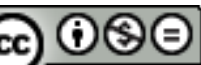

EY NC ND (C) 2014. This manuscript version is made available under the CC-BY-NC-ND 4.0 license http://creativecommons.org/licenses/by-nc-nd/4.0/

***Note: Tables can be found at the end of the article.

\begin{abstract}
:
Patients who are 65 years and older make up nearly half of intensive care unit (ICU) admissions and approximately $60 \%$ of the ICU hospital days in the United States. ${ }^{1}$ Cardiovascular (CV) conditions are commonly the first or second diagnosis on admission to the ICU. Furthermore, even if an elderly patient is not admitted for a CV condition, the physiologic stress of any acute illness challenges the heart, often producing structural or functional compromise. For example, acute ischemia or dysrhythmias may be the primary condition or a consequence of an initial physiologic insult.
\end{abstract}

Keywords: Cardiovascular | Critical care | Elderly | Nursing care | Heart failure | Myocardial infarction | Hypertension

Article:

\section{Introduction}

Patients who are 65 years and older make up nearly half of intensive care unit (ICU) admissions and approximately $60 \%$ of the ICU hospital days in the United States. ${ }^{1}$ Cardiovascular (CV) conditions are commonly the first or second diagnosis on admission to the ICU. Furthermore, even if an elderly patient is not admitted for a CV condition, the physiologic stress of any acute illness challenges the heart, often producing structural or functional compromise. For example, acute ischemia or dysrhythmias may be the primary condition or a consequence of an initial physiologic insult.

Critically ill elders are a physiologically diverse group. Their heterogeneity sometimes makes it difficult to separate physiologic aging from the pathology of disease. ${ }^{2}$ Moreover, as individuals age, comorbid conditions become more prevalent, making diagnosis and treatment of acute 
illnesses more challenging. In addition, medications used to treat underlying conditions further predispose elders to physiologic compromise during an acute illness.

The most common CV conditions that nurses encounter when caring for critically ill elders include hypertension (HTN), acute coronary syndromes (ACS), heart failure (HF), conduction disorders (eg, atrial fibrillation [AF]), and valvular heart disease. This article focuses primarily on the first 3 conditions because they have the highest prevalence in the elderly population. In all the conditions, however, there are common threads among elderly patients hospitalized in the ICU. First, cognitive decline among some elderly patients makes history taking challenging for health care providers, regardless of the presenting condition. Second, because symptoms in elders are often subtle, it is frequently difficult to tease out new symptoms from symptoms related to an acute exacerbation of a chronic CV condition. In addition, some elders have underlying conditions that have not been formally diagnosed or treated in the past, making interpretation of diagnostic testing difficult because baseline comparisons are unavailable. Finally, as individuals age, they experience decline in kidney and liver function, which influences laboratory findings (eg, cardiac biomarkers, such as troponin or brain natriuretic peptide values) and the way that individuals are treated medically.

\section{Physiologic changes to the heart}

Age-related changes to the CV system affect both the physiologic functioning of the heart and the way elderly individuals respond to medical therapy to treat CV conditions. These changes occur progressively over time; however, some individuals decline more rapidly than others. ${ }^{1}$ Some of the physiologic changes are related to chronologic age itself, whereas others are related to lifestyle. As a result of these physiologic changes, over time, there are decreases in maximal heart rate (HR), ejection fraction (EF), and cardiac output (CO). Table 1 gives a summary of age-related physiologic changes to the heart. ${ }^{1-4}$

\section{TABLE 1 CAN BE FOUND AT THE END OF THE ARTICLE}

\section{Hypertension}

\section{Burden of the condition}

Approximately two-thirds of adults age 65 and older have HTN, and this figure increases to nearly $80 \%$ among those 75 and older. This is primarily because as individuals age, systolic blood pressure (SBP) tends to steadily increase, regardless of whether the individuals are being treated for HTN. ${ }^{5}$ Diastolic blood pressure (DBP), on the other hand, peaks in the fourth or fifth decade of life, then steadily decreases over time. ${ }^{5}$ Therefore, when considering baseline blood pressure (BP) readings outside the hospital, it is common for most elders to have isolated systolic HTN. $^{4}$

Unfortunately, only about three-fourths (71\%) of adults age 65 and older are aware that they have the HTN. ${ }^{6}$ Furthermore, among those diagnosed with HTN, only about $69 \%$ receive treatment and fewer than half (48.8\%) reach BP treatment goals. ${ }^{6}$ Control rates are worse for elders age 80 and older, with only $38 \%$ of men and $23 \%$ of women meeting BP treatment 
goals. ${ }^{6}$ For these reasons, elders are more likely to have complications related to uncontrolled HTN.

Hypertension crisis

One of the complications of uncontrolled HTN is an HTN crisis, which occurs in approximately $1 \%$ to $2 \%$ of those with HTN. ${ }^{7}$ Although this percentage is low compared with the high prevalence of HTN in elders, the consequences of having an HTN crisis can be devastating. Formerly referred to as malignant HTN or accelerated HTN, currently an HTN crisis may be classified as HTN urgency or HTN emergency. Distinguishing between an urgent and an emergent HTN crisis is not based solely on BP measurement; instead, it is based on whether endorgan damage exists. ${ }^{7}$ Specifically, HTN urgency is defined as an abrupt rise in BP without signs of end-organ damage. HTN urgency typically occurs when the DBP is $120 \mathrm{~mm} \mathrm{Hg}$ or greater. Patients diagnosed with HTN urgency need to have their BP controlled within 24 hours to several days. ${ }^{7}$ This group of patients may be treated with oral medications on an outpatient basis.

In contrast, an HTN emergency is defined as an abrupt rise in BP that is associated with CV, kidney, or central nervous system end-organ damage. ${ }^{7}$ Individuals diagnosed with an HTN emergency require immediate medical attention because of the life-threatening nature of the situation and the increased likelihood of end-organ damage (encephalopathy, acute aortic dissection, stroke, ACS, acute pulmonary edema, and kidney failure). These patients are typically admitted to the ICU for treatment. Thus, the remainder of this section related to HTN crisis, focuses on this group of critically ill elders.

\section{Cause of an HTN crisis}

Most patients who have an HTN crisis have uncontrolled HTN as their baseline, but many of them have never been formally diagnosed with high BP. Other common risk factors include kidney disease (renal artery stenosis, glomerulonephritis, or renal cell carcinoma), endocrine disorders (diabetes, Cushing syndrome, primary hyperaldosterism, pheochromocytoma), drugs (cocaine, sympathomimetics, abrupt withdrawal of some antihypertensive agents), central nervous system disorders (head or spinal cord injury, cerebral infarction or hemorrhage, brain tumor), and postoperative pain or complications. ${ }^{7}$ However, the mechanisms that trigger an HTN crisis on a particular day are not completely understood. Normally at baseline, even with fluctuations in BP throughout the day, an individual's compensatory mechanisms allow for a relatively constant perfusion to vital organs. ${ }^{8}$ Yet, in the case of an HTN crisis, an initial insult serves as the stimulus to abruptly increase BP. ${ }^{7}$ The arterioles sense this sharp increase in BP and signal to the vascular endothelium to release nitric oxide (a vasodilator) as a means to compensate. ${ }^{7}$ In addition, the arterial smooth muscle contracts to reduce the rise in BP. Over time, however, the endothelium is unable to release enough nitric oxide to buffer the severe and sudden rise in BP. Compensatory mechanisms fail as a result of prolonged arterial smooth muscle contraction, a gradual increase in endothelial dysfunction, and an inability to release more nitric oxide, resulting in rapid and progressive decompensation of vital organ function. ${ }^{7,8}$ One of the most serious consequences of a HTN emergency is cerebral edema and microhemorrhages that result from the elevated pressure. These are due to the inability of the brain's autoregulation to tolerate sudden severe changes in BP (increases or decreases). Thus, 
neurologic deficits occur due to the vasodilation, edema, and increased intracranial pressure (ICP). Interestingly, some patients with a long history of HTN are able to tolerate the acute increase in mean arterial pressure (MAP) without increasing cerebral perfusion, thereby avoiding an increase in ICP.

\section{Obtaining accurate BP readings in elders}

It is imperative that nurses measure BP correctly for all patients in the ICU, especially those with suspected HTN emergencies. Nurses need to consider 3 things that affect BP readings: (1) physiologic differences in elders that may influence manual or noninvasive readings; (2) differences in values obtained by noninvasive and invasive methods; and (3) differences between SBP versus MAP readings. Nurses should know that it is common for elderly patients to have an ausculatory gap, a period during manual BP measurement when the true SBP fades away, then recurs at a lower pressure point. ${ }^{4}$ This is usually associated with vascular disease caused by longstanding HTN. Thus, when taking manual BP readings, the cuff needs to be inflated high enough to capture the true starting point of the SBP, or otherwise the reading may be falsely low. Additionally, some elders have pseudohypertension, a falsely elevated SBP resulting from markedly sclerotic arteries that will not collapse as the BP cuff is inflated. ${ }^{4}$ To assess for this abnormality, the nurse should palpate the pulse distal to the location of the BP cuff during measurement. ${ }^{4}$ If the pulse remains palpable, despite having the BP cuff inflated above the SBP, the nurse should suspect pseudohypertension. In this case, only direct measurement of BP (eg, via an arterial line) will reveal an accurate BP. ${ }^{4}$

Nurses also need to be aware of the differences between noninvasive blood pressure (NIBP) readings and invasive arterial pressure readings, which are made when patients experience extremes in BP. ${ }^{9}$ Specifically, when a patient is hypotensive, the NIBP runs higher than invasive BP for SBP readings. When a patient is hypertensive, the NIBP runs lower than with the invasive method. Thus, during hypotensive or hypertensive episodes, the NIBP may not capture the full extent of deviation. Furthermore, NIBP systolic readings are not as sensitive as intra-arterial readings in assessing a patient's risk of developing acute kidney injury. Lehman and colleagues ${ }^{9}$ advise that if NIBP readings are used, nurses should avoid hypoperfusion in those at risk for acute kidney injury; parameters for the lower limit of the SBP should be higher than the usual threshold of lower than $90 \mathrm{~mm}$ Hg. These findings, however, do not mean that an invasive method should be used to obtain BP in every patient in the ICU, just that these differences should be considered.

Regardless of which method is used to obtain the BP, the MAP is a more consistent metric than SBP to use to guide therapy in the ICU. ${ }^{9}$ The MAP is the "true driving pressure" for peripheral blood flow. ${ }^{9}$ Unfortunately, nursing practice has been slow to adopt use of MAP, especially when NIBP methods are used. Generally, the upper threshold for MAP is between 60 and 65 mm $\mathrm{Hg}$, but goals may be individualized by the medical team based on comorbid conditions. ${ }^{9}$

\section{Evaluation of patients with HTN emergencies}

In addition to obtaining accurate BP readings, it is vital to conduct a thorough history and physical examination as part of the admission assessment of a patient with an HTN emergency. 
If the patient is unable to provide the information, the nurse should ask whether someone close to the patient (a family member, caregiver, partner) is available to provide the information. Assessment of medical history should include history of antihypertensive treatment, including adherence to the regimen, illicit drug use, symptoms of other CV conditions (eg, HF, angina, aortic dissection), symptoms of neurologic deficits (eg, nausea, vomiting, headache, mental status changes, weakness, blurred vision), and symptoms of kidney disease (eg, hematuria or oliguria). In addition, ascertaining whether the patient has a history of thyroid disease, Cushing syndrome, systemic lupus, or systemic sclerosis is helpful in determining potential causes.

A focused physical examination should include a CV and neurologic assessment. As part of the $\mathrm{CV}$ examination, BP should be measured in both arms, to check for differences. In addition, the nurse should assess for absent or delayed peripheral pulses (to rule out dissection), auscultate heart and lung sounds (extra heart sounds, such as an $S_{3}$, or adventitious lung sounds, such as rales, to rule out pulmonary edema), and check the mental status of the patient as part of neurologic checks (to rule out cerebral hypoperfusion). A fundoscopic examination should also be done by the medical team to assess for soft exudates, hemorrhages, and papilledema. Diagnostic tests should include a 12-lead electrocardiogram (ECG), a chest radiograph, a brain computed tomography scan, and laboratory assessments, including urinalysis, electrolytes with a serum creatinine, complete blood count, cardiac enzymes (especially if acute ischemia is suspected), and BNP, especially if acute HF is suspected.

\section{Treatment of HTN crises}

Treatment for an HTN crisis is challenging because there is a lack of evidence-based guidelines for clinical care, especially for elders. However, there are general treatment recommendations for patients with an HTN emergency. The first order of treatment, in addition to determining whether the HTN crisis is an emergent crisis or an urgent crisis, is to address and control any acute precipitating causes (eg, anxiety, pain, hypoxia, hypercapnia, or hypoglycemia). ${ }^{10}$ The patient also should be admitted to the ICU and given parenteral medications to reverse end-organ damage related to an HTN emergency. ${ }^{10}$ During this time, intra-arterial BP monitoring is required when using certain intravenous (IV) medications, to obtain the most accurate readings. ${ }^{10}$

When treating a patient with an HTN emergency, a critical point to remember is that the BP does not need to be corrected urgently. Too rapid reduction of BP can result in serious ischemia, cortical blindness, hemiplegia, acute myocardial infarction (MI), and/or acute kidney failure, especially with elders who have long-standing HTN. ${ }^{10}$ Instead, allowing a patient's autoregulation to adapt to the clinical situation by decreasing the BP more slowly results in better outcomes. The treatment goal is to restore normal perfusion pressure to the vital organs, not to reach the "normal” target BP goal established for outpatients. 8

Initially BP measurements should be assessed every 5 to 10 minutes (after the first measurement is obtained). ${ }^{10}$ A good rule of thumb is that the MAP should be lowered over a period of 2 to 6 hours after the time of presentation, but not by more than $25 \%$ of the initial value at presentation. ${ }^{7}$ This should translate to about a $10 \%$ decrease in the first hour, with another $15 \%$ decrease over the next 2 to 3 hours. ${ }^{7}$ To accomplish this, medications need to be effective within the first hour after diagnosis. ${ }^{10}$ An exception to this rule is patients experiencing an aortic 
dissection. In this case, the target SBP should be $120 \mathrm{~mm} \mathrm{Hg}$ within the first 20 minutes; then an SBP between 100 and $120 \mathrm{~mm}$ Hg should be maintained. ${ }^{7}$ To do so, medications need to be effective within the first 10 minutes after diagnosis. ${ }^{10}$ In the case of an aortic dissection, because SBP is being lowered more rapidly than in other HTN emergencies, the nurse should monitor the patient closely for signs and symptoms of cerebral hypoperfusion (eg, nausea, headache, confusion, psychomotor slowing, or agitation). Table 2 provides a summary of steps in the nursing care of patients with HTN emergencies, including specific BP goals for various clinical situations.

\section{TABLE 2 CAN BE FOUND AT THE END OF THE ARTICLE}

\section{Treatment for HTN emergencies}

In addition to avoiding an abrupt reduction in BP, nurses treating elders with HTN emergencies should start with lower doses of medications, assess for side effects frequently, and be aware that many elders are admitted with a fluid volume deficit. Volume depletion on arrival at the ICU is likely to be due to pressure-induced natriuresis, which may be the patient's baseline status if the patient is dehydrated, especially in the summer months. ${ }^{4,11}$ Thus, unless there are clear signs of fluid overload, administration of loop diuretics should be avoided in elders presenting with an HTN emergency. In fact, in some cases of volume depletion, patients may need volume expansion.

There are different routes of administration for medications to treat HTN emergencies. The IV route is most common because of the relatively short half-life, making these agents easier to titrate, more flexible to use, more likely to have a rapid onset of action, and more likely to have a shorter duration. ${ }^{9}$ It is important to note that sublingual administration of phentolamine, clonidine, diazoxide, or nifedipine is contraindicated due to the likelihood of severe hypotension with use. ${ }^{9}$

Most IV agents require intra-arterial BP monitoring and continuous ECG monitoring during the acute phase of an HTN emergency to assess for changes in perfusion status. ${ }^{9}$ Some agents are preferred over others, depending on the patient's condition(s) at the time of presentation (eg, cerebral edema, aortic dissection, acute ischemic or hemorrhagic stroke, ACS, acute HF, or acute kidney failure, or if a patient is in the acute postoperative setting). Once the BP is stabilized with IV medications, a conversion to oral therapy typically occurs within 6 to 12 hours. ${ }^{6}$

Table 3 provides information on the most common medications used to treat HTN emergencies.

\section{TABLE 3 CAN BE FOUND AT THE END OF THE ARTICLE}

\section{Heart Failure}

Burden of the condition

As with HTN, the prevalence of HF increases with age; about half of the adults with HF in the US are at least age $75 .{ }^{12,13}$ It is generally considered a condition of elders. ${ }^{14} \mathrm{HF}$ is the leading cause of hospitalization for those age 65 and older. ${ }^{6,14,15}$ At baseline, elders with HF are more 
likely to be women, to have preserved systolic function (ie, normal EF), and to have isolated systolic HTN as the precipitating cause of HF. ${ }^{12}$ Younger adults with HF are more likely to be men, have systolic dysfunction, and to have an ischemic etiology. ${ }^{12}$ However, of those elders who are admitted with HF, the percentage with systolic dysfunction is higher than among those in the community. ${ }^{12,13}$

Systolic HTN is the greatest risk factor for the development of HF, especially among women. ${ }^{12,13}$ In addition to increased age and systolic HTN, risk factors for HF in the elderly include having coronary heart disease (CHD), AF, a widened pulse pressure, diabetes, chronic lung disease, kidney dysfunction, left ventricular hypertrophy (LVH), and obesity. Age-related changes to the CV system (eg, increased arterial and ventricular stiffness, impaired betaadrenergic responsiveness), combined with age-related changes to the kidneys and lungs, place elders at risk for the development of HF. ${ }^{12,13}$ These combined age-related effects and comorbid conditions also influence the ability of elders to compensate during an exacerbation of $\mathrm{HF}$ and their response to treatment during exacerbations.

\section{Acute decompensation of HF}

Acute decompensated heart failure (ADHF) is a clinical classification of rapidly worsening HF and is primarily diagnosed by a patient's signs and symptoms. ${ }^{15,16}$ Approximately $80 \%$ of individuals with ADHF have chronic HF that acutely decompensates, known as "acute on chronic HF." 16,17 These patients typically present with a history of progressive, worsening chronic HF, usually with evidence of either systemic or pulmonary congestion. ${ }^{15,16}$ The remaining $20 \%$ of patients with ADHF have new-onset HF. ${ }^{16}$ During acute episodes, the reninangiotensin-aldosterone system (RAAS) is activated, causing an increase in sodium and water retention by the kidneys, an increase in circulating blood volume, and an increase in venous pressure. ${ }^{12,15}$ Fluid accumulates in the lung's interstitial and alveolar spaces, resulting in acutely elevated cardiac filling pressures. ${ }^{15,16}$ These high-risk patients require immediate medical attention, are usually hospitalized in the ICU, and receive acute pharmacologic therapy.

\section{Precipitating factors for ADHF}

Decompensation is typically caused by one or more precipitants; rarely does ADHF occur because of a sudden decline in the structure or function of the heart. ${ }^{15,16}$ Instead, decompensation is usually associated with worsening comorbid conditions (eg, worsening kidney function), a gradual decline in myocardial function, and/or persistent neurohormonal activation caused by the chronic underlying cardiac condition. ${ }^{15,16}$ Reasons for decompensation may differ based on the type of HF a patient has. For example, the primary reason for decompensation in patients with reduced EF is impaired contractility (increased end-systolic volume), often due to ischemia. ${ }^{12,13}$ Elderly patients who have increased systemic vascular resistance, higher norepinephrine levels, and impaired kidney function are more likely to go into acute HF, especially during times of ischemia. ${ }^{12}$

In contrast, the primary reason for decompensation in patients with preserved EF is inability to increase left ventricular (LV) stroke volume due to the presence of increased vascular stiffness, despite increased LV filling pressures. ${ }^{12}$ This group experiences impaired relaxation of the LV, 
and thus has difficulty receiving blood into the ventricle. In the past, it was thought that transient systolic dysfunction, acute ischemia, or mitral regurgitation played the primary role in acute pulmonary edema in these patients. However, a more current view of the pathogenesis of acute pulmonary edema is that it is a consequence of markedly elevated SBP. ${ }^{12,18}$ There are several pathophysiological mechanisms for decompensation in patients with preserved EF (abnormalities in ventricular diastole, vascular stiffness, circulatory volume overload, and atrial dysfunction) all more likely with advanced age. ${ }^{12,18}$ Increases in LV mass and LV volume from long-standing HTN, diabetes, or obesity further compromise the patient. ${ }^{12}$ Also, because LV relaxation is sensitive to changes in afterload and HR, patients can more easily decompensate during episodes of HTN or tachycardia. ${ }^{12}$ Box 1 provides a list of possible precipitants of ADHF.

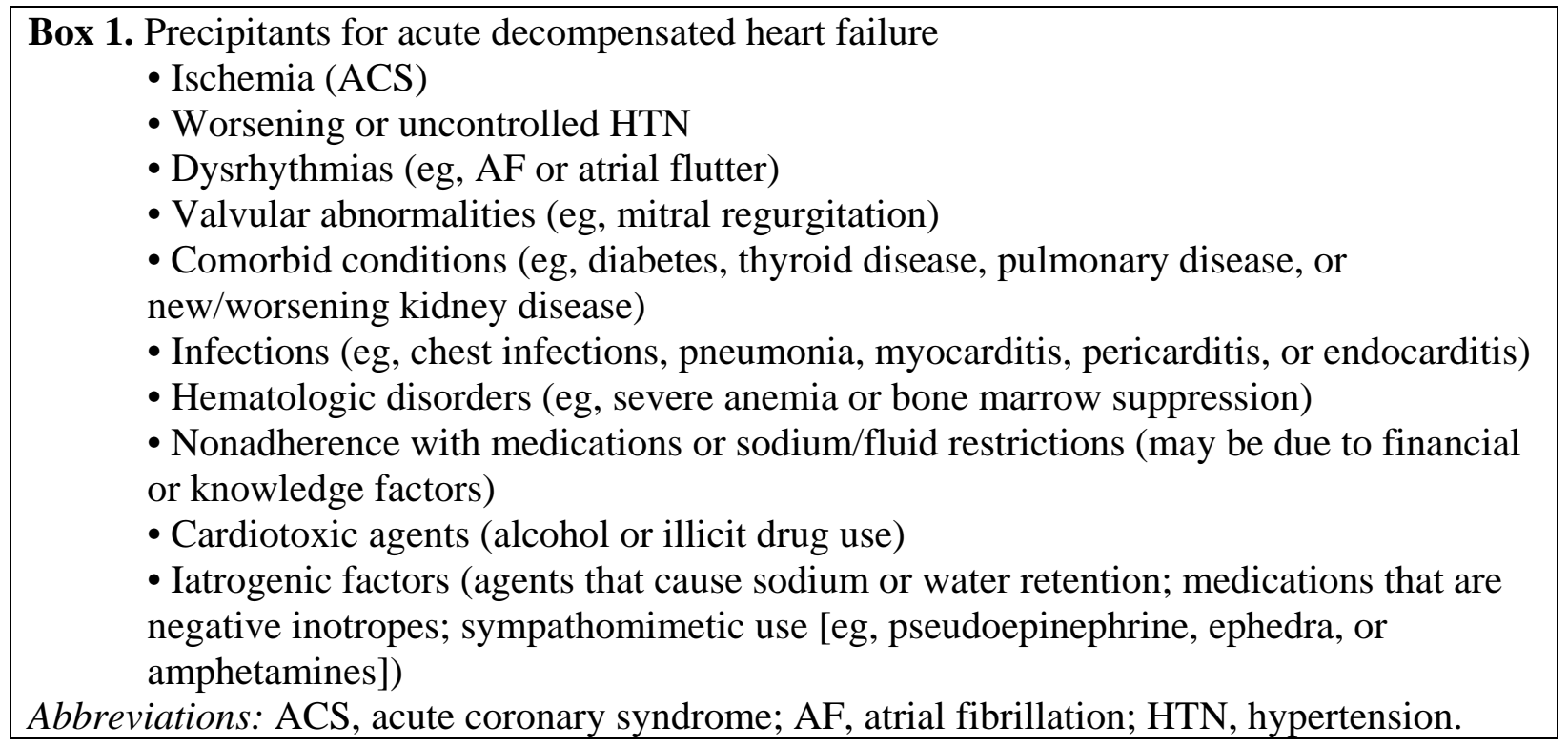

Signs and symptoms of ADHF

Assessing symptoms of HF is challenging in elderly patients because they are more likely to attribute their symptoms to getting older, being deconditioned, or being obese. They are also unlikely to report exertional symptoms if they lead a sedentary life. ${ }^{12}$ As with many CV conditions, their symptoms are also more likely to be atypical (eg, somnolence or malaise, weakness or confusion, irritability, anorexia, general abdominal complaints, sleep disturbance, or decreased activity). ${ }^{12}$ However, nurses should be knowledgeable about the classic presentations of ADHF.

The most common presentation of ADHF includes pulmonary and systemic congestion without a decline in cardiac output. ${ }^{15}$ In fact, many patients (30\%-50\%) who are evaluated in the emergency department or hospitalized for ADHF have systemic HTN (SBP>140 mm Hg) at the time of evaluation, not hypotension. ${ }^{15}$ Cardinal signs and symptoms of ADHF include shortness of breath, congestion, and fatigue. ${ }^{12,14,15}$ Congestion may occur as pulmonary congestion or as systemic congestion. Thus, nurses should keep in mind that pulmonary congestion may be present, even in the absence of rales/crackles or evidence of fluid on the chest radiograph. ${ }^{14,15}$ Although not the majority, some patients present with low output (inadequate 
tissue perfusion). Symptoms of inadequate perfusion may be more subtle than those of congestion, especially in elders. ${ }^{12}$ Therefore, nurses should be able to recognize the signs and symptoms of low output promptly, because cardiogenic shock may be imminent in patients who have low cardiac output. ${ }^{12}$ Table 4 lists the signs/symptoms of ADHF.

\section{TABLE 4 CAN BE FOUND AT THE END OF THE ARTICLE}

\section{Diagnosis of ADHF}

The diagnosis of ADHF is primarily based on the patient's clinical signs and symptoms. ${ }^{14,15}$ However, there are some tests that are useful in confirming the diagnosis, assessing the severity of disease, and evaluating the results of therapy. Two sub-types of natriuretic peptides, B-type natriuretic peptide (BNP) and N-terminal pro-B-type natriuretic peptide (NT-proBNP), may be ordered to increase certainty about the diagnosis. ${ }^{14,15}$ These naturally occurring hormones, secreted from the atria and ventricles as a result of cardiac dilation, have been found to be highly predictive in diagnosing patients with HF, regardless of whether they have a normal EF or low EF. ${ }^{14,15}$ Both types of hormones increase with age, particularly in women, in obese individuals, and in those with kidney impairment. ${ }^{15}$ Assay specificity is lower for elders, especially older women with preserved LV function (age 70105 years), than for younger patients (18-69 years) with HF. ${ }^{15}$ NT-proBNP has a longer half-life and in general runs about 4 times higher than BNP. ${ }^{15}$ Despite these limitations in specificity, there are cut points for diagnosis. A BNP level greater than $500 \mathrm{pg} / \mathrm{mL}$ is considered diagnostic of ADHF. ${ }^{15}$ The cut point for a positive diagnosis of ADHF by NT-proBNP testing is based on age: higher than $450 \mathrm{pg} / \mathrm{mL}$ for patients younger than 50, higher than $900 \mathrm{pg} / \mathrm{mL}$ for those age 50 to 75 years, and higher than $1800 \mathrm{pg} / \mathrm{mL}$ for those older than $74 .{ }^{15}$ Although natriuretic peptides may be helpful in improving diagnostic certainty, the usefulness of serial measurement of these tests to reduce hospitalization or mortality is not well established. ${ }^{14}$ Furthermore, current recommendations for the treatment of HF advise that natriuretic peptides may be useful in the outpatient setting to optimize medical therapy. ${ }^{14}$ However, more research is needed before recommending widespread use.

Echocardiography is considered the gold standard noninvasive test for diagnosing and monitoring HF. ${ }^{12,14,15}$ An echocardiogram provides information about both cardiac structure and function, including estimates of LVEF, wall motion abnormalities, and the integrity of the heart valves, all of which are helpful in sorting out the etiology of the HF. However, standard echocardiography is unable to distinguish diastolic dysfunction related to "normal" aging from HF. ${ }^{12,14,15}$ Thus, it is best to combine standard echocardiography with Doppler imaging to ensure accurate assessment diastolic function.

Other diagnostic tests typically done for patients admitted with ADHF include chest radiograph (to rule out cardiac enlargement, pulmonary congestion, pleural effusion, pneumothorax, and/or the placement of cardiac devices), 12-lead ECG (to assess heart rate and rhythm or the presence of LVH or acute ischemia), and standard laboratory studies (serum electrolytes, including calcium, magnesium, and phosphorus, complete blood count, serum albumin, uric acid, liver function tests, and thyroid function studies). ${ }^{14,15}$ 


\section{Treatment of ADHF}

Primary treatment goals for patients admitted with ADHF include improving symptoms (especially symptoms of congestion and low output), restoring oxygenation, and optimizing volume status. ${ }^{12,14,15}$ In addition, hospitalization provides an opportunity for the medical team to reevaluate the ongoing treatment regimen to ensure that the patient is receiving guidelinedirected medical therapy for optimal short-term and long-term outcomes. Box 2 lists the treatment goals for patients hospitalized with ADHF.

\section{Box 2. Treatment goals for acute decompensated heart failure Data from Refs. ${ }^{12,14-16}$ \\ - Improve symptoms, especially those related to congestion and low output \\ - Restore oxygenation \\ - Optimize volume status \\ - Identify the etiology of the HF \\ - Identify and correct precipitating factors \\ - Optimize chronic therapy \\ - Minimize side effects of treatment regimen \\ - Identify which patients may benefit from revascularization and/or device therapy \\ - Identify which patients are candidates for anticoagulation therapy (high risk for thromboembolism) \\ - Educate patients and families concerning treatment regimen and self-assessment of $\mathrm{HF}$ \\ - Refer to a disease management program if available \\ Abbreviation: HF, heart failure.}

Many clinicians use a classification system to assign a clinical profile to patients with ADHF to guide pharmacologic therapy with IV diuretics, inotropes, and/or vasodilators. Classification systems differentiate clinical profiles based on the adequacy of tissue perfusion ("warm" vs "cold") and the degree of congestion ("wet" vs "dry"). ${ }^{14-16}$ The most frequent presentation of ADHF is the "warm and wet" clinical profile. ${ }^{15,16}$ Patients with this profile should generally be treated with IV loop diuretics or an increased dose or increased frequency of oral diuretics, because of their congestion. ${ }^{14-16}$ In addition to diuretics, vasodilators (such as nitroglycerin, sodium nitroprusside, or nesiritide) may be used for patients with this profile, as their BP generally permits use. ${ }^{14-16}$ Patients with a second type of clinical profile, those who are "cold and wet," are also treated with IV loop diuretics because the etiology of hypoperfusion is likely to be congestion. However, diuretics may be minimally effective if perfusion to the kidneys is affected by the low output. ${ }^{14-16}$ Regardless of the presence or absence of congestion, inotropes (eg, dopamine, dobutamine, or milrinone) are used for all patients classified as "cold" to assist with circulation. ${ }^{14-16,19}$ The third profile, "warm and dry," is actually the "target" profile that is desired after treatment. However, if patients who present with ADHF have adequate perfusion and are without congestion, treatment should focus on searching for other causes of their HF (such as ACS, pulmonary embolus, infection, anemia, hypothyroidism, or depression). ${ }^{14-16}$ In this case, they should not receive IV diuretics (to avoid hypotension). The final profile for hospitalized patients with ADHF is the "cold and dry" clinical profile, which is least prevalent. Inotropes are the treatment of choice because of the hypoperfusion ("the coldness"). ${ }^{14-}$ 
${ }^{16,19}$ Diuretics and vasodilators are not given because of the potential for marked hypotension or irreversible organ damage. ${ }^{14-16}$ Table 5 provides a summary of the clinical profiles and general treatment recommendations.

\section{TABLE 5 CAN BE FOUND AT THE END OF THE ARTICLE}

Regardless of which clinical profile the patient has, there are general principles that nurses should consider when administering IV diuretics, vasodilators, and inotropes to patients with ADHF. Generally considered first-line agents, IV loop diuretics should be given to all patients with evidence of fluid overload. ${ }^{12,14-16}$ Administration by the IV route is preferred over the oral route because of better effectiveness and a faster clinical response (as rapidly as 15 minutes in some patients) with IV diuresis. ${ }^{14-16,19}$ Symptomatic relief is generally obtained within 1 to 2 hours, compared with oral maintenance doses, which may take weeks to rid excess fluid. ${ }^{15}$ If the patient has a history of chronic HF and decompensates acutely, the initial dose of IV diuretic should equal to or exceed their long-term oral daily dose. ${ }^{14,16}$ Higher doses may be needed for those with kidney disease or those with severe fluid overload to gain symptomatic relief. ${ }^{14,15}$ Current treatment guidelines for ADHF do not specify a preference for intermittent bolus injections of IV diuresis versus a continuous infusion. ${ }^{14,15}$ Advantages of intermittent bolus injections include the convenience of administering the medication at a specific time and that continuous IV access is not required. ${ }^{16,20}$ However, some patients do not respond to intermittent bolus injections; thus, a continuous infusion of a loop diuretic should be considered. ${ }^{14-}$

16,20 Advantages to a continuous infusion include a more constant delivery of the agent to the kidneys and less chance of causing prerenal azotemia, less chance of causing side effects from fluctuations in drug levels, and less chance of developing rebound sodium reabsorption if the drug were to drop below the therapeutic range. ${ }^{16,20}$ Other recommendations for patients who do not respond to the initial dose of IV diuresis include increasing the dose of the loop diuretic, adding a second type of diuretic (thiazide) to work synergistically with the loop diuretic, implementing a sodium and fluid restriction for the patient, and consideration of ultrafiltration, if available at the facility. ${ }^{14-16,20}$ In contrast, for patients who develop worsened kidney function after receiving IV diuresis, treatment options include a temporary dose decrease or discontinuation of the diuretic, use of vasodilator or inotrope therapy, or short-term hemodialysis may be considered for patients who have continued fluid volume overload in the setting of worsened kidney function. ${ }^{16}$ Table 6 gives information on IV diuretics used to treat ADHF.

\section{TABLE 6 CAN BE FOUND AT THE END OF THE ARTICLE}

Vasodilators, generally considered second-line agents, are best used for patients who have volume overload, yet normal or elevated BP (ideally an SBP of $>110 \mathrm{~mm} \mathrm{Hg}$ ). ${ }^{14-16,19}$ All IV vasodilators need to be administered by an infusion pump, and some facilities require invasive hemodynamic monitoring when administering some of these agents (such as sodium nitroprusside). ${ }^{14-16}$ Inotropes are typically considered a third-line agent in some patients with ADHF because current guidelines deemphasize the use of inotropes as compared with vasodilators. However, IV inotropes are a good option for patients who have symptomatic hypotension ( $\mathrm{SBP}<90 \mathrm{~mm} \mathrm{Hg}$ ) or borderline SBP who are unable to receive vasodilators safely. Inotropes help patients with severe systolic dysfunction, hypotension, or evidence of low cardiac output, with or without congestion, to maintain systemic perfusion and preserve end-organ 
performance. ${ }^{14-16,19}$ Table 6 also provides information on IV vasodilators and IV inotropes used to treat ADHF.

Other miscellaneous medications for ADHF

Traditionally, IV morphine has been used to stabilize patients with acute pulmonary edema. However, recent studies have shown that morphine given to acutely ill patients with ADHF is associated with worse outcomes (longer hospital stay, need for mechanical ventilation, need for ICU, and higher overall mortality). ${ }^{15}$ The mechanism related to this association is unclear. Thus, the current guidelines for treatment of ADHF indicate that morphine should be used cautiously, especially in those with impaired respiratory drive or altered mental status. ${ }^{15,16}$ If used at all, morphine should be given at low doses $(2.5-5.0 \mathrm{mg}$ ) and the patient should be monitored for side effects (eg, hypotension, bradycardia, advanced heart block, and carbon dioxide retention). ${ }^{15}$

Digoxin is generally not used in the acute setting of ADHF. However, some patients may be on digoxin before hospitalization (eg, those with preexisting HF or AF) and may continue to receive the medication throughout their hospital stay. Although digoxin helps decrease symptoms of HF, the use of this agent has not been shown to improve survival, especially in the acute setting. The use of digoxin in managing patients with ADHF is not addressed in the current treatment guidelines. ${ }^{15,16}$ If digoxin is used, doses are generally lower than previously advised, especially in elders or those with kidney dysfunction. ${ }^{12}$ This is largely due to an analysis of the Digitalis Investigation Group (DIG) study, which showed that the maximum benefit of digoxin was evident at serum levels of 0.5 to $0.8 \mathrm{ng} / \mathrm{mL}{ }^{12,21} \mathrm{In}$ fact, digoxin levels greater than 1.2 (previously thought to be "therapeutic") were associated with increased mortality. ${ }^{12,21}$ Thus, a dosage of $0.125 \mathrm{mg}$ daily is adequate for most elders with normal kidney function; and a lower dosage ( $0.125 \mathrm{mg} 1-3$ times per week) is appropriate for those with impaired kidney function. ${ }^{12,22}$

Aspirin is also not indicated for ADHF, unless the patient has a known history of CHD or is experiencing acute cardiac ischemia. If aspirin is given, the lowest dosage (81 mg daily) should be used to minimize the chance of bleeding or interaction with angiotensin-converting enzyme (ACE) inhibitors. ${ }^{15,16}$

Maintenance therapies in the setting of ADHF

Medications given in the acute ICU setting for ADHF are generally given to improve the patient's symptoms and hemodynamics. However, hospitalization also offers an opportunity to optimize long-term therapy for patients transitioning from the hospital to the community. Longterm benefits of maintenance therapies include attenuating (slowing down) the disease process, decreasing the chances of rehospitalization, and improving survival. Maintenance therapy includes ACE inhibitors (or angiotensin receptor blockers [ARBs], if allergic), beta-adrenergic antagonists (beta-blockers), loop diuretics, aldosterone antagonists, and digoxin (for some patients with reduced LVEF). ${ }^{12,14,15}$ However, nurses should be aware that elders are at increased risk for side effects from these therapies. For example, because elders have a greater likelihood of underlying chronic kidney disease and renal artery stenosis, they are at an increased risk of orthostatic hypotension or worsened kidney function when given ACE inhibitors, especially if 
patients take nonsteroidal anti-inflammatory drugs. ${ }^{12}$ Elders are also at higher risk for kidney dysfunction and electrolyte abnormalities with the use of diuretic therapy. ${ }^{12,14}$ Thus, the lowest possible dose of diuretic should be used, while still maintaining euvolemia (normal fluid volume status). ${ }^{12}$ Thus, the in-patient setting may provide an opportunity for close monitoring that would otherwise not be available as an outpatient to monitor for these potential side effects (especially if patients have borderline or low BP, a low HR, or have borderline electrolyte abnormalities). Box 3 provides pearls for starting or up-titrating maintenance therapies for patients who have been hospitalized for ADHF.

In rare circumstances, a patient's baseline therapy may have to be temporarily discontinued when they are admitted for ADHF. For example, if the patient with chronic HF is admitted with cardiogenic shock, refractory volume overload, or symptomatic bradycardia, then it would be appropriate to temporarily discontinue or give half their usual dose of beta-blocker (as opposed to complete discontinuation of the medication). ${ }^{15}$ Also if the patient's SBP is lower than $80 \mathrm{~mm}$ Hg, is experiencing symptomatic hypotension, or has a markedly elevated creatinine compared with baseline, ACE inhibitor (or ARB) therapy should be reduced or temporarily discontinued until kidney function improves. ${ }^{15}$ Finally, if a patient's kidney function dramatically worsens or their potassium become markedly elevated ( $>5.5 \mathrm{mEq} / \mathrm{L}$ ) aldosterone antagonists (spironolactone or eplerenone) should be temporarily discontinued until the potassium has normalized or the kidney function has returned to baseline. ${ }^{15}$

\section{Box 3. Pearls for starting or up titrating maintenance therapies}

Data from Lindenfeld J, Albert NM, Boehmer JP. Heart Failure Society of America, executive summary: HFSA 2010 comprehensive heart failure practice guideline. J Card Fail

2010;16(6):e1-194; and Coons JC, McGraw M, Murali S. Pharmacotherapy for acute heart failure syndromes. Am J Health Syst Pharm 2011;68:21-35.

- ACE-inhibitors (or ARBs) can be started (or up-titrated) if the kidney function is stable.

- Doses of ACE inhibitors (or ARBs) can be adjusted more frequently in the in-hospital setting, because side effects and laboratory findings can be monitored more closely.

- Generally, patients should be on target doses of ACE inhibitors (or ARBs) and on a low-dose diuretic before starting beta-blocker therapy for chronic HF.

- For patients who are newly diagnosed with HF, beta-blocker therapy should be started at the lowest dose 24 hours before hospital discharge, after the volume status is optimized, successful conversion of IV to oral diuretics has occurred, and after all vasodilators or inotropes have been weaned off.

- Patients on chronic beta-blocker therapy who are not yet at target doses may have their beta-blocker up-titrated 24 hours before hospital discharge (with the same conditions as above).

- After hospital discharge uptitration of beta-blocker and ACE-inhibitor therapy should occur every 2 to 4 weeks during a face-to-face visit to allow for assessment of vital signs and fluid volume.

Abbreviations: ACE, angiotensin-converting enzyme; ARB, angiotensin receptor blocker; HF, heart failure; IV, intravenous. 
Elders in the ICU are at an increased risk for acute cardiac ischemia, either from ACS or from the physiologic stress to the heart from other acute illnesses. Some patients with ACS have a history of stable angina that escalates prior to the event; others have no prior symptoms.

The diagnosis of ACS is an umbrella term that includes patients with unstable angina (UA), nonST-Segment-Elevation MI (NSTEMI), or ST-Segment-Elevation MI (STEMI). UA refers to acute ischemic symptoms that increase in frequency and severity over time, often occurring at rest, either due to an increased demand for myocardial oxygen or a decreased supply (subtotal occlusion) of one or more coronary arteries. ${ }^{6}$ The ischemia is transient and reversible, thus does not result in necrosis (death) of the myocardial tissue as with MI. ${ }^{6}$ In contrast, an MI involves a total occlusion of at least one coronary artery, resulting in irreversible necrosis of the tissue that is supplied by the infarct-related artery. An STEMI is diagnosed if a symptomatic patient's 12lead ECG has acute ST-segment elevation in 2 or more contiguous leads; whereas, patients who have ischemic symptoms without ST-segment elevation on their 12-lead ECG, yet rule in for an MI by cardiac enzymes (eg, creatine kinase MB [CK-MB] or troponin levels), are classified as NSTE MI.

Burden of the condition in elders

As individuals age, they are at greater risk for having an ACS event. ${ }^{23,24}$ The median age for first-time MI in the United States is approximately 65 for men and 74 for women. ${ }^{5}$ Furthermore, $35 \%$ of all MIs occur in persons 75 and older; $11 \%$ occurring in persons 85 and older. ${ }^{23}$ Although the absolute numbers of patients with STEMI increases with age, elders are more likely to have an NSTE MI. ${ }^{24}$ This is because elders are more likely to have complex calcified CHD, prior revascularization, and ACS due to other (secondary) conditions (eg, pneumonia, gastrointestinal bleeding, or sepsis). ${ }^{23,24}$

Advanced age is also an independent predictor for complications following an ACS event, including a higher risk of HF, bleeding, mechanical complications, and death. ${ }^{24}$ In addition, ACS accounts for $35 \%$ of all deaths in adults 65 years and older, which increases sharply after the age of $75 .{ }^{24}$ However, evidence-based treatment has been shown to improve mortality and morbidity in elderly patients with ACS, although not equal the outcomes of younger patients. ${ }^{23,24}$ Possible reasons for worse outcomes in elders include longer delays in seeking care, a higher burden of underlying CHD (often undiagnosed), more end-organ damage, and more comorbid conditions, all of which influence the effectiveness of treatment options. ${ }^{23}$

Signs and symptoms of ACS

Chest pain is the most common symptom of ACS. However, as individuals age, they are more likely to have atypical symptoms, such as dyspnea, diaphoresis, nausea and vomiting, unusual fatigue, and syncope. ${ }^{23}$ Thus, some elders may attribute atypical symptoms of ACS to other bodily conditions. Furthermore, elders are also more likely to have silent ischemia (no symptoms) with their ACS event compared with younger patients. ${ }^{23}$ Symptoms of NSTEMI ACS usually manifest in 1 of 3 ways: (1) as rest angina (angina at rest, usually longer than 
20 minutes), (2) new-onset angina (usually markedly limiting the person's activities), or (3) as progressively increasing angina (increased frequency, increased duration, or a lower threshold of what precipitates symptoms) in patients with preexisting CHD. ${ }^{25}$

\section{Evaluation of ACS}

Initial evaluation of patients with known or suspected ischemia should include a focused history (current symptoms, CV risk factors, and past medical history) and physical examination (check HR, BP, heart rhythm, heart and lung sounds, peripheral pulses, and presence of peripheral edema). In addition, all patients with known or suspected ischemia should have a 12-lead ECG performed within 10 minutes of hospital presentation. While obtaining a 12-lead ECG, the patient should be given aspirin (160-325 mg, nonenteric coated), unless contraindicated. ${ }^{25}$ Aspirin should not be held while awaiting the 12-lead ECG. Unfortunately, many elderly patients, especially women or those with atypical symptoms, experience delay in receiving ECGs within the desired 10-minute time frame. In addition, elderly patients are more likely to have nondiagnostic ECGs or ECGs with abnormal baseline findings (eg, LVH, AF, bundle branch block, paced rhythms, or a prior MI), which confound the ability to detect acute ST-segment/T-wave changes. ${ }^{23}$ If the first ECG is nondiagnostic, yet the patient remains highly symptomatic, additional ECGs may be done every 15 to 30 minutes to detect possible ST-Twave changes. ${ }^{25}$ It is also important to obtain serial cardiac biomarkers (CK total, CK-MB, and troponin [the preferred biomarker]) to see if the patient has ruled in for an MI. ${ }^{25}$ However, troponin levels could be elevated for reasons other than ACS (eg, myocardial contusion, sepsis, pulmonary embolus, stroke, or advanced kidney disease). ${ }^{1,23}$

\section{Treatment of ACS}

Studies have shown that many elders experiencing an ACS event do not receive evidence-based treatment. ${ }^{23-25}$ As a result, in 2007 the American Heart Association (AHA) published a 2-part scientific statement on acute coronary care in the elderly, specifically addressing the care of elders suffering from NSTE ACS (Part I) and STEMI (Part II). ${ }^{24,25}$ In addition, the latest AHA guidelines for ACS and STEMI also include a special groups section for treating older adults. ${ }^{26,27}$

All patients diagnosed with ACS who have continuing symptoms or hemodynamic instability should be admitted for at least 24 hours to the ICU..$^{25}$ These patients should receive continuous ECG monitoring for detection of arrhythmias, frequent assessments of vital signs and mental status, and continuous ST-segment monitoring (if available) to detect recurrent ischemia. ${ }^{25}$ The most sensitive leads for viewing the infarct-related artery include Lead III for the right coronary artery, Lead V3 for the left anterior descending artery, and Lead V5 for the lateral and left circumflex artery. If the patient has ST-segment depression or elevation as the baseline, adjustments may be made to the ECG alarm settings to account for the baseline abnormalities. In addition, each patient should have access to defibrillation by the health care team if the patient experiences ventricular fibrillation. ${ }^{25}$ If the patient does not have major complications within the first 24 hours, he or she may be moved out of the ICU. Examples of major complications include sustained ventricular arrhythmias, sinus tachycardia, high-grade atrioventricular block, sustained hypotension, recurrent ischemia (documented by symptoms or ST-segment deviation), new mitral regurgitation, or HF, any of which would keep the patient in the ICU. ${ }^{25}$ 
In addition, patients should receive supplemental oxygen by nasal cannula or facial mask if they have oxygen saturation less than 90\%, are experiencing respiratory distress, or have other highrisk features for respiratory compromise. ${ }^{25}$ Beyond continuous ECG monitoring and oxygen, treatment recommendations for elders with ACS are extrapolated from data with younger patients because most clinical trials have not included patients older than 75 . In the ACS trials that have included elders, subgroup analysis has shown that in-hospital mortality decreases significantly as the number of recommended therapies given in the acute setting increases (eg, early use of aspirin, nitroglycerin, beta-blockers, ACE-inhibitors, heparin, glycoprotein IIb/IIIa inhibitors with percutaneous coronary intervention [PCI], and early cardiac catheterization $\left[<48\right.$ hours]). ${ }^{23}$ In fact, adults 75 and older with positive troponin levels (eg, NSTE MI) have been shown to gain a greater absolute benefit with an early invasive strategy (cardiac catheterization within 48 hours) compared with younger adults, mainly because of the much worse outcomes for elders who are treated more conservatively. ${ }^{23}$ Table 7 lists the recommended pharmacologic agents for treating patients with NSTE MI and UA.

\section{TABLE 7 CAN BE FOUND AT THE END OF THE ARTICLE}

Treatment of STEMI should include urgent reperfusion therapy. ${ }^{23}$ Prompt reperfusion therapy (PCI within 90 minutes or fibrinolytic therapy within 30 minutes of hospital arrival) has shown a clear mortality benefit compared with not receiving reperfusion therapy, even for patients up to age $85 .^{23,25}$ Selection of reperfusion therapy generally favors PCI (vs fibrinolytic therapy). ${ }^{23,25}$ However, the choice of reperfusion therapy also depends on risks and benefits for the individual patient, the time that symptoms began, and availability within the facility at the time of patient presentation. ${ }^{23,25}$ PCI is especially beneficial in elders with cardiogenic shock, prior stroke, large anterior infarcts, or those who present later in their symptom course (>6 hours). ${ }^{23}$ Benefits of urgent PCI include reduction in ischemic events and need for infarctrelated artery revascularization, improved 30-day survival, and lower risk of hemorrhagic stroke at 30 days. $^{23}$

Monitoring elders for bleeding

Several of the therapies (eg, antiplatelet and antithrombin agents) used to treat ACS have an accompanied risk of bleeding. With elders, bleeding is a function of age, comorbid conditions (eg, impaired kidney function, anemia as a baseline, diabetes, low body weight, prior history of bleeding, alterations in hemostatic factors that help individuals clot) and concomitant medication use. ${ }^{23,27}$ Furthermore, bleeding is also related to excess dosing due to small body size and lower

creatinine clearance. ${ }^{24,27}$ Kidney function should be determined by calculating the patient's creatinine clearance, rather than using the serum creatinine. Nurses should also be diligent in monitoring elders for bleeding when these agents are given. Signs of bleeding may be more subtle and, if present, elders may downplay the symptoms. If a bleed is noted, the nurse should stop the offending agent (if known) and notify the medical team.

\section{Summary}


Nurses working in the ICU will frequently encounter elderly patients with CV conditions, either as the primary or secondary diagnosis. However, it is challenging to distinguish between pathology of disease and physiologic changes due to aging. Nurses need to assess patients carefully because signs and symptoms are more likely to be more subtle or atypical in elders as compared with younger patients. Nurses also should monitor elderly patients more closely to watch for side effects of medications, especially if underlying kidney or liver impairment exists. Finally, although elders may be at increased risk for side effects of therapy, studies have shown that patients in their advanced years have the most benefit to gain with use of guideline-directed medical therapy.

\section{References}

1. Pisani MA. Considerations in caring for the critically ill older patient. J Intensive Care Med 2009;24(2):83-95.

2. Suttner SW, Piper SN, Boldt J. The heart in the elderly critically ill patient. Curr Opin Crit Care 2002;8:389-94.

3. Marik PE. Management of the critically ill geriatric patient. Crit Care Med 2006; 34(9):S17682.

4. Wright JD, Hughes JP, Ostchega Y, et al. Mean systolic and diastolic blood pressure in adults aged 18 and over in the United States, 2001-2008. Natl Health Stat Report 2011;35:1-22, 24.

5. Aronow WS, Fleg JL, Pepine CJ, et al. ACCF/AHA 2011 expert consensus document on hypertension in the elderly: a report of the American College of Cardiology Foundation Task Force on Clinical Expert Consensus Documents. J Am Coll Cardiol 2011;57:2037-114.

6. Go AS, Mozaffarian D, Roger VL, et al. Heart disease and stroke statistics-2013 update: a report from the American Heart Association. Circulation 2013;127:e6-245.

7. Johnson W, Nguyen ML, Patel R. Hypertension crisis in the emergency department. Cardiol Clin 2012;30:533-43.

8. Thomas L. Managing hypertensive emergencies in the emergency department. Can Fam Physician 2011;57:1137-41.

9. Lehman LH, Saeed M, Talmor D, et al. Methods of blood pressure measurement in the ICU. Crit Care Med 2013;41(1):34-40.

10. Slama M, Modeliar SS. Hypertension in the intensive care unit. Curr Opin Cardiol 2006;21:279-87.

11. Feldstein C. Management of hypertensive crises. Am J Ther 2007;14:135-9. 
12. Maurer MS, Kitzman D. Essentials of cardiovascular care in older adults (ECCOA) curriculum. Heart Failure in older adults. Available at: http://www.cardiosource.org/ACC/ACCMembership/Member-Sections-andCouncils/w/media/Files/ACC/Member\%20Section\%20Documents/ECCOA/Heart\%20Failure\%2 0in\%20Older\%20Adults\%20\%20Case\%201\%20of\%203.ashx. Accessed September 29, 2013.

13. Kannel WB. Incidence and epidemiology of heart failure. Heart Fail Rev 2000;5:167-73.

14. Yancy CW, Jessup M, Bozkurt B, et al. 2013 ACCF/AHA guideline for the management of heart failure: a report of the American College of Cardiology Foundation/American Heart Association Task Force on practice guidelines. J Am Coll Cardiol 2013;62(16):1495-539.

15. Lindenfeld J, Albert NM, Boehmer JP. Heart Failure Society of America, executive summary: HFSA 2010 comprehensive heart failure practice guideline. J Card Fail 2010;16(6):e1-194.

16. Coons JC, McGraw M, Murali S. Pharmacotherapy for acute heart failure syndromes. Am J Health Syst Pharm 2011;68:21-35.

17. Gheorghiade M, Pang PS. Acute heart failure syndromes. J Am Coll Cardiol 2009;53:55773.

18. Gandi SK, Powers JC, Nomeir AM, et al. The pathogenesis of acute pulmonary edema associated with hypertension. N Engl J Med 2001;344:17-22.

19. Coons JC, Seidl E. Cardiovascular pharmacotherapy update for the intensive care unit. Crit Care Nurs Q 2007;30(1):44-57.

20. Felker GM, Lee KL, Bull DA, et al. Diuretic strategies in patients with acute decompensated heart failure. N Engl J Med 2011;364:797-805.

21. Rich MW, McSherry F, Williford WO, et al. Effect of age on mortality, hospitalizations and response to digoxin in patients with heart failure: the DIG study. J Am Coll Cardiol 2001;38:806-13.

22. Rathore SS, Curtis JP, Wang Y, et al. Association of serum digoxin concentration and outcomes in patients with heart failure. J Am Med Assoc 2003;289:871-8.

23. Alexander K, Alpert J, Gharacholou M, et al. Essentials of cardiovascular care in older adults (ECCOA) curriculum. Overview: acute coronary syndromes in older adults. Available at: http://www.cardiosource.org/ACC/ACC-Membership/Member-Sections-andCouncils/w/media/Files/ACC/Member\%20Section\%20Documents/ECCOA/Acute\%20Coronary \%20Syndromes\%20in\%20Older\%20Adults\%20Overview.ashx. Accessed September 29, 2013.

24. Alexander KP, Newby LK, Cannon CP, et al. Acute coronary care in the elderly, Part 1: nonST-Segment-Elevation acute coronary syndromes a scientific statement for healthcare 
professionals from the American Heart Association Council on Clinical Cardiology. Circulation 2007;115:2549-69.

25. Anderson JL, Adams CD, Antman EM, et al. 2012 ACCF/AHA focused update incorporated into the ACCF/AHA 2007 guidelines for the management of patients with unstable angina/nonST-elevation myocardial infarction: a report of the ACCF/AHA task force on practice guidelines. Circulation 2013;127:e663-828.

26. Alexander KP, Newby K, Armstrong PW, et al. Acute coronary care in the elderly, Part II: ST-segment-elevation myocardial infarction. A scientific statement for healthcare professionals from the American Heart Association Council on Clinical Cardiology. Circulation 2007;115:2570-89.

27. Alexander KP, Chen AY, Roe MT, et al. Excess dosing of anti-platelet and antithrombin agents in the treatment of non-ST segment elevation acute coronary syndromes. J Am Med Assoc 2005;294:3108-16. 
Table 1. Physiologic changes to the heart related to aging

\begin{tabular}{|c|c|c|}
\hline Physiologic Change & Physiologic Mechanism & Consequences \\
\hline $\begin{array}{l}\text { Gradual loss of } \\
\text { physiologic reserve }\end{array}$ & $\begin{array}{l}\text { - Physiologic stress (eg, blood loss, hypoxia, } \\
\text { sepsis, volume depletion). } \\
\text { - Vasoconstriction and sodium/water retention in } \\
\text { the short term } \uparrow \text { CO. } \\
\text { - Vasoconstriction persists to } \uparrow \text { afterload. } \\
\text { Eventually heart fails to overcome } \uparrow \text { afterload. }\end{array}$ & $\begin{array}{l}\text { - More vulnerable to disease. } \\
\text { - LV volume } \uparrow \text { over time } \rightarrow \text { fluid in alveoli; pulmonary edema } \\
\text { develops. } \\
\text { - Maximum oxygen uptake } \downarrow \text {; hypoxemia occurs resulting in poor } \\
\text { tissue/cellular perfusion. } \\
\text { - CV function } \downarrow \text {. } \\
\text { - Kidney function } \downarrow \text {. } \\
\text { - Elasticity of skin and lungs } \downarrow \text {. }\end{array}$ \\
\hline $\begin{array}{l}\text { Decreased response } \\
\text { to sympathetic } \\
\text { stimulation }\end{array}$ & $\begin{array}{l}\text { - Overall, declining receptor function and } \\
\text { autonomic dysregulation. } \\
\text { - Activity of SNS } \uparrow \text { due to receptor dysfunction. } \\
\text { - Activity of beta-receptor function } \downarrow \text {. } \\
\text { - Baroreceptor reflex response } \downarrow \text {. }\end{array}$ & $\begin{array}{l}\text { - Orthostatic hypotension may result. } \\
\text { - Less likely to } \uparrow \mathrm{HR} \text { to compensate for } \downarrow \mathrm{CO} \text {. } \\
\text { - Need to } \uparrow \text { preload or ventricular filling and stroke volume to } \\
\text { compensate. } \\
\text { - If hypovolemia exists, more likely to decompensate. }\end{array}$ \\
\hline $\begin{array}{l}\text { Increased stiffness } \\
\text { of heart and blood } \\
\text { vessels }\end{array}$ & $\begin{array}{l}\text { - Arteriosclerotic process creates stiff arterial and } \\
\text { ventricular walls. } \\
\text { - Stiff ventricular walls become dependent on } \\
\text { atrial contraction (atrial kick). } \\
\text { - Atrial dilatation occurs as ventricles become } \\
\text { stiff. }\end{array}$ & $\begin{array}{l}\text { - Atrial kick needed for diastolic filling. } \\
\text { - Atrial kick lost if in atrial fibrillation ( } \downarrow \text { diastolic filling time). } \\
\text { - Increased resistance to ventricular ejection due to } \downarrow \text { ventricular } \\
\text { compliance. } \\
\text { - Diastolic dysfunction results. }\end{array}$ \\
\hline $\begin{array}{l}\text { Increased incidence } \\
\text { of hypertension }\end{array}$ & - Arterial distensibility $\downarrow$, especially large vessels. & $\begin{array}{l}\text { - More likely to have isolated systolic HTN. } \\
\text { - Afterload } \uparrow \text {; more likely to develop LVH. } \\
\text { - Progressive kidney dysfunction. }\end{array}$ \\
\hline $\begin{array}{l}\text { Increased incidence } \\
\text { of ischemic heart } \\
\text { disease }\end{array}$ & $\begin{array}{l}\text { - Longer exposure to risk factors and becoming } \\
\text { less active. } \\
\text { - More likely to } \uparrow \text { HR with physiologic stress to } \\
\text { maintain CO; exacerbates ischemia. }\end{array}$ & $\begin{array}{l}\text { - Rate-related ischemia more common. } \\
\text { - Symptoms may be atypical or absent. }\end{array}$ \\
\hline $\begin{array}{l}\text { Increased incidence } \\
\text { of heart failure }\end{array}$ & $\begin{array}{l}\text { - Progressive } \downarrow \text { of cardiac myocytes. } \\
\text { - Progressive } \uparrow \text { in myocardial collagen. } \\
\text { - Arterial distensibility } \downarrow \text { resulting in } \downarrow \text { CO. } \\
\text { - CO less responsive to } \uparrow \mathrm{HR} \text {; have to } \uparrow \text { preload } \\
\text { to maintain (or } \uparrow \text { ) CO. }\end{array}$ & $\begin{array}{l}\text { - Resting CO more likely to be maintained. } \\
\text { - Acute illness } \uparrow \text { dysfunction. } \\
\text { - More likely to have impaired relaxation (diastolic dysfunction). } \\
\text { - More dependent on preload. } \\
\text { - Minor changes in fluid status may cause decompensation. }\end{array}$ \\
\hline $\begin{array}{l}\text { Increased incidence } \\
\text { of dysrhythmias }\end{array}$ & $\begin{array}{l}\text { - Autonomic tissue replaced by connective tissue } \\
\text { and fat. } \\
\text { - Fibrosis creates conduction abnormalities } \\
\text { through intranodal tract and bundle of His. }\end{array}$ & $\begin{array}{l}\text { - May lead to sick sinus syndrome, atrial dysrhythmias, or bundle } \\
\text { branch blocks. } \\
\text { - Atrial dysrhythmias most common. } \\
\text { - Sudden loss of atrial kick with atrial dysrhythmia may cause angina, } \\
\text { HF, and/or } \downarrow \text { BP. }\end{array}$ \\
\hline
\end{tabular}


Abbreviations: BP, blood pressure; CO, cardiac output; CV, cardiovascular; HF, heart failure; HR, heart rate; HTN, hypertension; LV, left ventricular; LVH, left ventricular hypertrophy; SNS, sympathetic nervous system; $\uparrow$, increase; $\downarrow$, decrease.

Data from Refs. ${ }^{1-4}$

Table 2. Nursing care for hypertensive emergencies

General BP goals: Lower MAP within 2-6 h of presentation, no more than $25 \%$ of the initial value at presentation. BP should be decreased $~ 10 \%$ in the first hour, then $\sim 15 \%$, gradually over $2-3 \mathrm{~h}$. Exception: aortic dissection (see below).

\begin{tabular}{|c|c|c|}
\hline $\begin{array}{l}\text { Consequences of } \\
\text { HTN Emergency }\end{array}$ & Signs and Symptoms & Implications for Treatment \\
\hline Encephalopathy & $\begin{array}{l}\text { - Symptoms of cerebral edema or hypoperfusion: } \\
\text { nausea/vomiting, headache, psychomotor agitation or } \\
\text { slowing, visual changes, stupor, seizures, delirium, or } \\
\text { papilledema. } \\
\text { - Rare focal neurologic deficits include: paralysis, } \\
\text { paresthesias, loss of muscle control/tone in a specific part of } \\
\text { the body; voice, vision, or hearing loss. }\end{array}$ & $\begin{array}{l}\text { - Target BP: MAP lowered by maximum } 20 \% \text { or to DBP } \\
100-110 \text { mm Hg within the first hour, then gradual reduction } \\
\text { in BP to "normal” range over } 48-72 \mathrm{~h} \text {. } \\
\text { - Medications of choice: intravenous sodium nitroprusside or } \\
\text { labetalol. }\end{array}$ \\
\hline $\begin{array}{l}\text { Ischemic stroke } \\
\text { or intracerebral } \\
\text { hemorrhage }\end{array}$ & $\begin{array}{l}\text { - Focal neurologic deficits (as above) suggest ischemic stroke } \\
\text { or intracerebral hemorrhage. }\end{array}$ & $\begin{array}{l}\text { - Target BP for ischemic stroke: MAP lowered no more than } \\
15 \%-25 \% \text {, DBP should not be }<100-110 \mathrm{~mm} \mathrm{Hg} \text { in first } 24 \mathrm{~h} \text {. } \\
\text { Some thrombolytic protocols may allow for more aggressive } \\
\text { BP goals. } \\
\text { - Target BP for ischemic stroke post-tPA: SBP }<180 \mathrm{~mm} \mathrm{Hg} \\
\text { or DBP }<110 \mathrm{~mm} \mathrm{Hg} \text {. } \\
\text { - Target BP for intracerebral hemorrhage: MAP lowered by } \\
20 \%-25 \% \text {. }\end{array}$ \\
\hline Aortic dissection & $\begin{array}{l}\text { - Abrupt onset of ripping or tearing sensation in the chest, } \\
\text { back, or both. } \\
\text { - May mimic symptoms of acute myocardial ischemia, acute } \\
\text { HF, stroke, musculoskeletal or pleuritic pain, or an acute } \\
\text { abdomen. } \\
\text { - Need to monitor for neurologic signs/symptoms of cerebral } \\
\text { hypoperfusion, especially if BP is reduced too fast. }\end{array}$ & $\begin{array}{l}\text { - Target BP: SBP } 120 \mathrm{~mm} \text { Hg after } 20 \text { min, then maintain at } \\
\text { 100-120 mm Hg. } \\
\text { - Medications of choice: combination of nitroprusside and } \\
\text { beta-blocker (esmolol or labetalol). } \\
\text { - Administer beta-blocker before nitroprusside because of the } \\
\text { rapid onset of action to avoid reflex tachycardia that could } \\
\text { worsen dissection. }\end{array}$ \\
\hline $\begin{array}{l}\text { Acute coronary } \\
\text { syndrome, } \\
\text { including acute } \\
\text { MI }\end{array}$ & $\begin{array}{l}\text { - Ischemic symptoms, such as pain or pressure in the jaw, } \\
\text { neck, chest, arm, or back. Atypical symptoms may include } \\
\text { dyspnea at rest or exertion, diaphoresis, and/or nausea. } \\
\text { - Some elders have silent ischemia. }\end{array}$ & $\begin{array}{l}\text { - Target BP: MAP } 60-100 \mathrm{~mm} \text { Hg. } \\
\text { - Medications of choice: nitrates (nitroglycerin) and beta- } \\
\text { blockers. } \\
\text { - Avoid enalaprilat, nicardipine, or hyralazine (may induce } \\
\text { reflex tachycardia and } \uparrow \text { workload of heart). }\end{array}$ \\
\hline
\end{tabular}




\begin{tabular}{|c|c|c|}
\hline $\begin{array}{l}\text { Consequences of } \\
\text { HTN Emergency }\end{array}$ & Signs and Symptoms & Implications for Treatment \\
\hline LV failure & $\begin{array}{l}\text { - Acute pulmonary edema may be the cause or consequence } \\
\text { of HTN crisis. } \\
\text { - } \uparrow \text { shortness of breath, hypoxia, pulmonary edema on } \\
\text { examination or x-ray. }\end{array}$ & $\begin{array}{l}\text { - Target BP: MAP 60-100 mm Hg. } \\
\text { - Medications of choice: sodium nitroprusside, nitroglycerin, } \\
\text { IV enalaprilat, loop diuretics. Avoid labetalol, esmolol, and } \\
\text { nicardipine in acute HF. }\end{array}$ \\
\hline $\begin{array}{l}\text { Acute renal } \\
\text { insufficiency }\end{array}$ & $\begin{array}{l}\text { - Proteinuria, elevated serum creatinine, hypokalemic } \\
\text { metabolic alkalosis, and microangiopathic hemolytic anemia. } \\
\text { - Level of kidney failure influenced by baseline kidney } \\
\text { function. }\end{array}$ & $\begin{array}{l}\text { - Target BP: MAP lowered by } 20 \%-25 \% \text {. } \\
\text { - Medication of choice: fenoldopam. } \\
\text { - Avoid use of sodium nitroprusside in acute renal } \\
\text { insufficiency. }\end{array}$ \\
\hline Postop HTN & $\begin{array}{l}\text { - Significantly elevated BP within } 2 \mathrm{~h} \text { after surgery. } \\
\text { - Common causes: sympathetic activation and adrenergic } \\
\text { surge postop, urinary retention, discontinuing anti-HTN } \\
\text { agents preop. }\end{array}$ & $\begin{array}{l}\text { - Target BP: MAP lowered by } 20 \%-25 \% \text {. } \\
\text { - Medication of choice: nicardipine, sodium nitroprusside, } \\
\text { esmolol, or labetalol. } \\
\text { - Caution: nicardipine may cause perioperative bleeding. }\end{array}$ \\
\hline
\end{tabular}

Abbreviations: BP, blood pressure; DBP, diastolic blood pressure; HF, heart failure; HTN, hypertension; IV, intravenous; LV, left ventricular; MAP, mean arterial pressure; Postop, postoperative; Preop, preoperative; SBP, systolic blood pressure; tPA, tissue plasminogen activator; $\uparrow$, increase. Data from Refs. $7,8,10,11$

Table 3. Common medications used to treat hypertensive emergencies

\begin{tabular}{|c|c|c|c|}
\hline Medication/Indication & Action & Dosing Information & $\begin{array}{l}\text { Nursing Implications (in Addition to Monitoring for } \\
\text { Hypotension) }\end{array}$ \\
\hline $\begin{array}{l}\text { Sodium nitroprusside } \\
\text { Most HTN } \\
\text { emergencies, except } \\
\text { acute HF. }\end{array}$ & $\begin{array}{l}\text { Vasodilator, arterial and } \\
\text { venous. } \\
\downarrow \text { preload and } \downarrow \downarrow \text { afterload. } \\
\text { (No effect on cardiac output.) } \\
\downarrow \text { pulmonary capillary wedge } \\
\text { pressure and central venous } \\
\text { pressure (by } \downarrow \text { preload). } \\
\downarrow \text { systemic vascular } \\
\text { resistance ( } \downarrow \text { afterload). }\end{array}$ & $\begin{array}{l}0.25-10 \mu \mathrm{g} / \mathrm{kg} / \mathrm{min} \mathrm{IV} \\
\text { infusion; maximum dose } \\
\text { for } 10 \text { min only. } \\
\text { Onset of action: seconds to } \\
2 \text { min. } \\
\text { Duration: } 1-3 \text { min. } \\
\text { Should start low and assess } \\
\text { frequently. }\end{array}$ & $\begin{array}{l}\text { Side effects: nausea/vomiting/ } \uparrow \text { ICP, may develop cyanide } \\
\text { toxicity (especially in those with kidney or liver } \\
\text { impairment), acidosis, coronary steal syndrome (can shunt } \\
\text { blood from diseased vessels to well-perfused vessels). } \\
\text { Watch for: cerebral hypoperfusion (due to } \uparrow \text { ICP), } \downarrow \\
\text { coronary perfusion, and ototoxicity. } \\
\text { Cautious use: elders and those with kidney impairment. } \\
\text { May } \downarrow \text { BP too rapidly. }\end{array}$ \\
\hline $\begin{array}{l}\text { Nitroglycerin } \\
\text { Most HTN } \\
\text { emergencies, especially } \\
\text { acute coronary } \\
\text { ischemia or post- } \\
\text { CABG. } \\
\text { Helpful if given in } \\
\text { combination with }\end{array}$ & $\begin{array}{l}\text { Vasodilator (venous dilation } \\
\text { with lower doses; arterial } \\
\text { dilation too with higher } \\
\text { doses). } \\
\text { Smooth muscle vasodilation } \\
\text { via nitric oxide. } \\
\downarrow \downarrow \text { preload and } \downarrow \text { afterload. } \\
\text { (No effect on cardiac output.) }\end{array}$ & $\begin{array}{l}5-100 \mu \mathrm{g} / \mathrm{min} \text { IV infusion. } \\
\text { Onset of action: } 2-5 \mathrm{~min} \text {. } \\
\text { Duration: } 5-10 \mathrm{~min} . \\
\text { Titrate to desired response. }\end{array}$ & $\begin{array}{l}\text { Administer in glass containers and use special tubing. } \\
\text { Side effects: headache, reflex tachycardia, vomiting, } \\
\text { flushing. } \\
\text { Tolerance may develop if administered continuously for } \\
24-48 \text { h. } \\
\text { Contraindications: cerebral hemorrhage ( } \uparrow \text { ICP) and } \\
\text { closed-angle glaucoma. }\end{array}$ \\
\hline
\end{tabular}




\begin{tabular}{|c|c|c|c|}
\hline Medication/Indication & Action & Dosing Information & $\begin{array}{l}\text { Nursing Implications (in Addition to Monitoring for } \\
\text { Hypotension) }\end{array}$ \\
\hline \multicolumn{4}{|l|}{$\begin{array}{l}\text { diuretics, especially for } \\
\text { acute pulmonary } \\
\text { edema. }\end{array}$} \\
\hline $\begin{array}{l}\text { Fenoldopam } \\
\text { Most hypertensive } \\
\text { emergencies, especially } \\
\text { acute kidney } \\
\text { impairment or acute } \\
\text { HF. }\end{array}$ & $\begin{array}{l}\text { Vasodilator, arterial. } \\
\text { Selective peripheral } \\
\text { dopamine-receptor agonist. } \\
\uparrow \text { perfusion to kidneys. } \\
\downarrow \text { afterload; } \uparrow \text { cardiac output; } \\
\text { no effect on preload. }\end{array}$ & $\begin{array}{l}0.1-0.6 \mu \mathrm{g} / \mathrm{kg} / \mathrm{min} \mathrm{IV} \\
\text { infusion; increments must } \\
\text { not exceed } 0.1 \mu \mathrm{g} / \mathrm{kg} / \mathrm{min} \\
\text { at } 20 \text {-min intervals. } \\
\text { Maximum dose: } \\
1.7 \mu \mathrm{g} / \mathrm{kg} / \mathrm{min} . \\
\text { Onset of action: } 4-15 \mathrm{~min} \text {. } \\
\text { Duration: } 30 \mathrm{~min}-4 \mathrm{~h} \text {. }\end{array}$ & $\begin{array}{l}\text { May administer without intra-arterial BP monitoring. May } \\
\text { withdraw without tapering. } \\
\text { Side effects: headache (common), flushing, dizziness, } \\
\text { reflex tachycardia or bradycardia, hypokalemia, } \uparrow \\
\text { intraocular pressure, local phlebitis. } \\
\text { Contraindications: patients with glaucoma or } \uparrow \text { intraocular } \\
\text { pressure. }\end{array}$ \\
\hline $\begin{array}{l}\text { Labetalol } \\
\text { Most hypertensive } \\
\text { emergencies, especially } \\
\text { aortic dissection and } \\
\text { pheochromocytoma } \\
\text { crisis. }\end{array}$ & $\begin{array}{l}\text { Sympathetic blocker. } \\
\text { Blocks alpha and beta- } \\
\text { receptors. } \\
\downarrow \text { afterload; } \downarrow \text { cardiac output; } \\
\text { no effect on preload. }\end{array}$ & $\begin{array}{l}20-80 \mathrm{mg} \text { IV bolus over } \\
2 \mathrm{~min} \text { every } 10 \mathrm{~min} \text { (total } \\
\text { dose } 300 \mathrm{mg} \text { ) or } 0.5- \\
2 \mathrm{mg} / \mathrm{min} \text { IV infusion. } \\
\text { Onset of action: } 5-10 \mathrm{~min} \text {. } \\
\text { Duration: } 2-6 \mathrm{~h} .\end{array}$ & $\begin{array}{l}\text { Side effects: bradycardia, heart block, worsened or new- } \\
\text { onset HF. } \\
\text { Contraindications: symptomatic bradycardia or heart } \\
\text { block; acute HF; reactive airway disease; cocaine toxicity. }\end{array}$ \\
\hline $\begin{array}{l}\text { Esmolol } \\
\text { Aortic dissection, } \\
\text { perioperative HTN } \\
\text { crises. Not for } \\
\text { catecholamine excess. }\end{array}$ & $\begin{array}{l}\text { Sympathetic blocker. } \\
\text { Ultrarapid, short-acting beta- } \\
1 \text { (cardioselective) blocker. } \\
\downarrow \text { cardiac output; no effect on } \\
\text { preload or afterload. }\end{array}$ & $\begin{array}{l}\text { 80-mg bolus over } 30 \mathrm{~s} \text {, } \\
\text { then } 150 \mu \mathrm{g} / \mathrm{kg} / \mathrm{min} \mathrm{IV} \\
\text { infusion. } \\
\text { Onset of action: } 1-2 \mathrm{~min} \text {. } \\
\text { Duration: } 10-20 \mathrm{~min} \text {. }\end{array}$ & $\begin{array}{l}\text { Requires intra-arterial BP monitoring. } \\
\text { Side effects: bradycardia, heart block, worsened or new- } \\
\text { onset HF; may cause thrombophlebitis and extravasation } \\
\text { (including local necrosis). } \\
\text { Contraindications: symptomatic bradycardia or heart } \\
\text { block; acute HF; reactive airway disease; cocaine toxicity. }\end{array}$ \\
\hline $\begin{array}{l}\text { Phentolamine } \\
\text { Catecholamine excess. }\end{array}$ & $\begin{array}{l}\text { Sympathetic blocker. } \\
\text { Nonselective alpha blocker. } \downarrow \\
\text { afterload; } \uparrow \text { cardiac output. } \\
\text { No effect on preload. }\end{array}$ & $\begin{array}{l}\text { 5-15-mg IV bolus. } \\
\text { Onset of action: } 1-2 \mathrm{~min} . \\
\text { Duration: } 10-15 \mathrm{~min} .\end{array}$ & Side effects: flushing, headache, reflex tachycardia. \\
\hline $\begin{array}{l}\text { Nicardipine } \\
\text { Most hypertensive } \\
\text { emergencies, including } \\
\text { perioperative and } \\
\text { postoperative HTN. }\end{array}$ & $\begin{array}{l}\text { Calcium channel blocker, 3rd } \\
\text { generation, dihydropyridine. } \\
\text { Arterial vasodilator. No } \\
\text { negative inotropic effects. } \\
\downarrow \text { afterload; } \uparrow \text { cardiac output; } \\
\text { no effect on preload. }\end{array}$ & $\begin{array}{l}\text { Dose: } 2-15 \mathrm{mg} / \mathrm{h} \text { as IV } \\
\text { infusion. } \\
\text { Onset: } 1-5 \mathrm{~min} \text {. } \\
\text { Duration: } 15-120 \mathrm{~min} \text {. } \\
\text { Dose independent of body } \\
\text { weight. Monitor and titrate } \\
\text { to lowest dose. }\end{array}$ & $\begin{array}{l}\text { Side effects: reflex tachycardia. } \\
\text { Cautious use: patients with CHD (tachycardia can } \uparrow \\
\text { ischemia) or those with suspected GI bleeding. }\end{array}$ \\
\hline
\end{tabular}




\begin{tabular}{|c|c|c|c|}
\hline Medication/Indication & Action & Dosing Information & $\begin{array}{l}\text { Nursing Implications (in Addition to Monitoring for } \\
\text { Hypotension) }\end{array}$ \\
\hline $\begin{array}{l}\text { Clevidipine } \\
\text { Most hypertensive } \\
\text { emergencies. }\end{array}$ & $\begin{array}{l}\text { Calcium channel blocker. } \\
\text { Relaxes smooth muscles; } \downarrow \\
\text { peripheral resistance. } \\
\downarrow \text { afterload; } \uparrow \text { cardiac output; } \\
\text { no effect on preload. }\end{array}$ & $\begin{array}{l}\text { 1-2 mg/h doubling the } \\
\text { dose at } 90 \text {-s intervals } \\
\text { initially; later at } 5-10-m i n \\
\text { intervals based on BP } \\
\text { effect. } \\
\text { Titrate to maximum } \\
16 \mathrm{mg} / \mathrm{h} \text { IV infusion. } \\
\text { (Usual dose } 4-6 \mathrm{mg} / \mathrm{h} \text { ). } \\
\text { Onset of action: } 1-4 \mathrm{~min} \text {. } \\
\text { Duration: } 5-15 \mathrm{~min} \text {. }\end{array}$ & $\begin{array}{l}\text { May administer in a central or peripheral IV line. } \\
\text { Side effects: Nausea, vomiting, headache, AF. } \\
\text { Contraindications: persons with AF; those who have soy } \\
\text { allergy. }\end{array}$ \\
\hline $\begin{array}{l}\text { Enalaprilat } \\
\text { For HTN emergencies, } \\
\text { especially acute HF. }\end{array}$ & $\begin{array}{l}\text { ACE inhibitor. } \\
\downarrow \text { afterload; } \uparrow \text { cardiac output; } \\
\text { no effect on preload. }\end{array}$ & $\begin{array}{l}1.25-5 \text { mg (over } 2-5 \text { min) } \\
\text { every } 6 \text { h IV bolus. } \\
\text { Onset of action: } 15- \\
30 \text { min. } \\
\text { Duration: } 12-24 \text { h. }\end{array}$ & $\begin{array}{l}\text { Side effects: headache, nausea, cough, hyperkalemia, } \\
\text { worsened kidney function. } \\
\text { Contraindication: History of ACE-inhibitor allergy or } \\
\text { angioedema. }\end{array}$ \\
\hline
\end{tabular}

Abbreviations: ACE, angiotensin-converting enzyme; AF, atrial fibrillation; BP, blood pressure; BUN, blood urea nitrogen; CABG, coronary artery bypass graft; CHD, coronary heart disease; GI, gastrointestinal; HF, heart failure; HTN, hypertension; ICP, intracranial pressure; IV, intravenous; $\uparrow$, increase; $\downarrow$, decrease; $\downarrow \downarrow$, more of a decrease.

Data from Refs. 7,10,11

Table 4. Signs and symptoms of acute decompensated heart failure

\begin{tabular}{|l|l|l|}
\hline Body Symptom & Sign/Symptoms of Pulmonary and Systemic Congestion & $\begin{array}{l}\text { Sign/Symptoms of Low Output (Inadequate Tissue } \\
\text { Perfusion) }\end{array}$ \\
\hline General & $\begin{array}{l}\text { Weight gain (or stable weight if anorexia present at baseline); } \\
\text { excessive thirst or dry mouth; may be apprehensive. }\end{array}$ & $\begin{array}{l}\text { Fatigue at rest, decreased exercise tolerance, weight loss, } \\
\text { cachexia, temporary wasting, lethargy, and somnolence. }\end{array}$ \\
\hline Cardiovascular & $\begin{array}{l}\text { JVD, S3 gallop, new-onset or increased mitral regurgitation, } \\
\text { right ventricular heave, increased central venous pressure or } \\
\text { right atrial pressure. }\end{array}$ & $\begin{array}{l}\text { Absent JVD, decreased systolic BP (<85 mm Hg or if } \\
\text { symptomatic), orthostatic BP and HR on standing, resting } \\
\text { tachycardia, decreased mean arterial pressure, narrow pulse } \\
\text { pressure, increased systemic vascular resistance, decreased } \\
\text { temperature. }\end{array}$ \\
\hline Pulmonary & $\begin{array}{l}\text { Dyspnea on exertion, orthopnea, paroxysmal nocturnal } \\
\text { dyspnea, nocturnal cough, rales, wheezes, pleural effusion, } \\
\text { tachypnea, decreased oxygen saturations, pulmonary edema } \\
\text { on chest x-ray. }\end{array}$ & $\begin{array}{l}\text { Dyspnea without orthopnea or paroxysmal nocturnal dyspnea, } \\
\text { dyspnea on exertion with clearbreath sounds, clear chest x- } \\
\text { ray, decreased oxygen consumption, decreased arterial oxygen } \\
\text { saturation. }\end{array}$ \\
\hline
\end{tabular}




\begin{tabular}{|l|l|l|}
\hline Body Symptom & Sign/Symptoms of Pulmonary and Systemic Congestion & $\begin{array}{l}\text { Sign/Symptoms of Low Output (Inadequate Tissue } \\
\text { Perfusion) }\end{array}$ \\
\hline Gastrointestinal & $\begin{array}{l}\text { Hepatomegaly, ascites, right upper quadrant tenderness, } \\
\text { nausea, vomiting, diarrhea, anorexia, elevated liver function } \\
\text { tests. }\end{array}$ & $\begin{array}{l}\text { Early satiety, anorexia, increased liver function } \\
\text { tests without hepatomegaly, right upper quadrant tenderness, } \\
\text { nausea, vomiting, bright red blood per rectum. }\end{array}$ \\
\hline Renal & $\begin{array}{l}\text { Urine output may be increased if oral intake is increased; } \\
\text { increased nocturia. }\end{array}$ & $\begin{array}{l}\text { Increased blood BUN, increased Cr, oliguria or anuria; } \\
\text { decreased serum sodium. }\end{array}$ \\
\hline Extremities & Warm pitting peripheral edema, strong peripheral pulses. & Cool; absent, or nonpitting edema; weak peripheral pulses. \\
\hline
\end{tabular}

Abbreviations: BP, blood pressure; BUN, blood urea nitrogen; Cr, creatinine; JVD, jugular vein distension.

Data from Refs. ${ }^{12,14-16}$

Table 5. Classification clinical profiles and treatment of acute decompensated heart failure

\begin{tabular}{|l|l|l|}
\hline Profile & Characteristics & Treatment \\
\hline Cold and wet & $\begin{array}{l}\text { Inadequate tissue perfusion } \\
\text { Congested }\end{array}$ & $\begin{array}{l}\text { IV loop diuretic (not as effective if kidney perfusion is compromised) } \\
\text { Inotropes (dopamine, dobutamine, or milrinone) }\end{array}$ \\
\hline Warm and wet & $\begin{array}{l}\text { Adequate tissue perfusion } \\
\text { Congested }\end{array}$ & $\begin{array}{l}\text { IV loop diuretic } \\
\text { Vasodilators (nitroglycerin, sodium nitroprusside, or nesiritide) }\end{array}$ \\
\hline Cold and dry: least common profile & $\begin{array}{l}\text { Inadequate tissue perfusion } \\
\text { Not congested }\end{array}$ & $\begin{array}{l}\text { Inotropes (as above) } \\
\text { Avoid use of diuretics and vasodilators due to profound hypotension or } \\
\text { irreversible organ damage }\end{array}$ \\
\hline $\begin{array}{l}\text { Warm and dry: the target } \\
\text { profile after treatment }\end{array}$ & $\begin{array}{l}\text { Adequate tissue perfusion } \\
\text { Not congested }\end{array}$ & $\begin{array}{l}\text { Search for other causes of HF. } \\
\text { Avoid IV diuretics to prevent hypotension }\end{array}$ \\
\hline
\end{tabular}

Abbreviations: HF, heart failure; IV, intravenous.

Data from Refs. ${ }^{12,14-16}$

Table 6. Intravenous medications used to treat acute decompensated heart failure

\begin{tabular}{|c|c|c|c|}
\hline $\begin{array}{l}\text { Medication } \\
\text { Class/Action(s) }\end{array}$ & Examples/Dose Recommendations & Side Effects & Nursing Implications \\
\hline $\begin{array}{l}\text { Loop diuretics } \\
\uparrow \text { urinary excretion of } \\
\text { sodium, chloride, and } \\
\text { water. } \\
\downarrow \text { circulating } \\
\text { intravascular volume ( } \downarrow \\
\text { preload and central } \\
\text { venous pressure). } \\
\downarrow \text { signs of fluid } \\
\text { retention. }\end{array}$ & $\begin{array}{l}\text { Furosemide } \\
\text { Loading IV dose: } 40 \mathrm{mg} \text {. } \\
\text { Continuous IV infusion should be adjusted to } \mathrm{CrCl} \text {; } \\
\text { typically } 10-40 \mathrm{mg} / \mathrm{h} \text {. } \\
\text { IV doses exceeding } 300 \mathrm{mg} / \mathrm{d} \text { in patients with } \\
\text { ADHF have increased mortality. } \\
\text { Bumetanide } \\
\text { Loading IV dose: } 1 \mathrm{mg} \text {. } \\
\text { Maximum IV dose: } 10 \mathrm{mg} / \mathrm{d} \text {. }\end{array}$ & $\begin{array}{l}\text { Most serious: If given too } \\
\text { rapidly may cause } \\
\text { symptomatic hypotension, } \\
\text { worsened kidney function, } \\
\text { serious serum electrolyte } \\
\text { abnormalities. } \\
\text { Most common: Worsened } \\
\text { kidney function ( } \uparrow \text { serum } \\
\text { BUN, creatinine). } \\
\text { Fluid volume deficit }\end{array}$ & $\begin{array}{l}\text { Monitor BP, HR, and cardiac } \\
\text { rhythm every 1-2 h. } \\
\text { Monitor signs and symptoms of } \\
\text { congestion and changes in body } \\
\text { weight. } \\
\text { Daily weights, comparing to } \\
\text { patient's dry weight (weight before } \\
\text { decompensation). } \\
\text { Monitor intake and output records. } \\
\text { Monitor serum electrolytes. Report }\end{array}$ \\
\hline
\end{tabular}




\begin{tabular}{|c|c|c|c|}
\hline Medication & Examples/Dose Recommendations & Side Effects & Nursing Implications \\
\hline & $\begin{array}{l}\text { Continuous IV infusion should be adjusted to } \mathrm{CrCl} \text {; } \\
\text { typically } 0.5-2 \mathrm{mg} / \mathrm{h} \text {. } \\
\text { Torsemide } \\
\text { Loading IV dose: } 20 \mathrm{mg} \text {. } \\
\text { Continuous IV infusion: typically } 5-20 \mathrm{mg} / \mathrm{h} \text {. }\end{array}$ & $\begin{array}{l}\text { (hypovolemia, } \\
\text { dehydration, orthostatic } \\
\text { hypotension, dizziness, } \\
\text { presyncope, syncope). } \\
\text { Electrolyte imbalances ( } \downarrow \\
\text { potassium, sodium, } \\
\text { calcium; metabolic } \\
\text { alkalosis; } \uparrow \text { glucose, lipid } \\
\text { levels, uric acid). } \\
\text { Less common: ototoxicity. }\end{array}$ & $\begin{array}{l}\text { abnormal values to the medical team } \\
\text { caring for the patient. } \\
\text { Instruct patient to change positions } \\
\text { slowly to avoid syncope. } \\
\text { Monitor for ringing in the ears or } \\
\text { hearing loss. }\end{array}$ \\
\hline \multirow{3}{*}{$\begin{array}{l}\text { Vasodilators } \\
\downarrow \text { BP ( } \downarrow \text { preload and } \\
\text { afterload by venous } \\
\text { and arterial } \\
\text { vasodilation). } \\
\downarrow \text { PCWP and CVP (by } \\
\downarrow \text { preload). } \\
\downarrow \text { SVR (afterload). } \\
\text { All need to be } \\
\text { administered by an IV } \\
\text { infusion pump. Patients } \\
\text { with a peripheral IV are } \\
\text { at risk for infiltration } \\
\text { and necrosis. } \\
\text { Monitor BP, HR, and } \\
\text { cardiac rhythm every } \\
1-2 \text { h. } \\
\text { Need to wean } \\
\text { vasodilators slowly to } \\
\text { avoid rebound } \\
\text { vasoconstriction. }\end{array}$} & $\begin{array}{l}\text { Nitroglycerin } \\
\text { Initial dose: } 10-20 \mu \mathrm{g} / \mathrm{min} \text {. } \\
\text { Typical dose range: } 5-200 \mu \mathrm{g} / \mathrm{min} \text {. } \\
\text { Adjustment increment: } 10-20 \mu \mathrm{g} / \mathrm{min} \text { every } 5- \\
15 \text { min. } \\
\text { Maximum dose: titrate up to a max of } 200 \mu \mathrm{g} / \mathrm{min} \text {. }\end{array}$ & $\begin{array}{l}\text { Symptomatic hypotension } \\
\text { (esp. if given with IV } \\
\text { diuretic), headache, } \\
\text { abdominal discomfort, } \\
\text { reflex tachycardia, } \\
\text { paradoxic bradycardia. }\end{array}$ & $\begin{array}{l}\text { May develop tolerance (decreased } \\
\text { response to drug) if receiving a } \\
\text { continuous infusion }>24 \mathrm{~h} \text {. }\end{array}$ \\
\hline & $\begin{array}{l}\text { Sodium nitroprusside } \\
\text { Initial dose: } 0.2-0.3 \mu \mathrm{g} / \mathrm{kg} / \mathrm{min} \text {. } \\
\text { Typical dose range: } 0.5-5 \mu \mathrm{g} / \mathrm{kg} / \mathrm{min} \text { (usually } 5-300 \\
\mu \mathrm{g} / \mathrm{min} \text { ). } \\
\text { Adjustment increment: } 0.25-0.50 \mu \mathrm{g} / \mathrm{kg} / \mathrm{min} \text { every } \\
\text { 5-15 min (while maintaining an SBP of }>90 \mathrm{~mm} \mathrm{Hg} \\
\text { or MAP }>65 \mathrm{~mm} \mathrm{Hg} \text { ). } \\
\text { Maximum dose: } 5 \mu \mathrm{g} / \mathrm{kg} / \mathrm{min} \text {. }\end{array}$ & $\begin{array}{l}\text { May cause profound } \\
\text { hypotension. } \\
\text { Serious side effects: } \\
\text { cyanide and thiocyanate } \\
\text { toxicities especially in } \\
\text { patients with liver or } \\
\text { kidney impairment. }\end{array}$ & $\begin{array}{l}\text { Need to monitor patients for cyanide } \\
\text { toxicity (change in mental status, } \\
\text { muscle spasms, convulsions, } \\
\text { hemodynamic instability, } \\
\text { unexplained metabolic or lactic } \\
\text { acidosis). Risk of toxicity } \downarrow \text { if given } \\
\text { at lower doses and used for }<72 \mathrm{~h} \text {. }\end{array}$ \\
\hline & $\begin{array}{l}\text { Nesiritide } \\
\text { Initial loading (bolus) dose: } 2 \mu \mathrm{g} / \mathrm{kg} \text {. (May omit } \\
\text { loading dose if there is concern for hypotension.) } \\
\text { Followed by infusion of: } 0.1 \mu \mathrm{g} / \mathrm{kg} / \mathrm{min} \text {. } \\
\text { Adjustment increment: } 0.005 \mu \mathrm{g} / \mathrm{kg} / \mathrm{min} \text {; bolus } \\
1 \mu \mathrm{kg} / \mathrm{min} \text { every } 3 \mathrm{~h} \text { to maximum dose. } \\
\text { Maximum dose: } 0.03 \mu \mathrm{g} / \mathrm{kg} / \mathrm{min} \text {. }\end{array}$ & $\begin{array}{l}\text { Symptomatic hypotension } \\
\text { (especially if given with } \\
\text { IV diuretic), headache, } \\
\text { worsening kidney } \\
\text { function (dose dependent). } \\
\text { Serious side effect: May } \\
\text { worsen ischemia in } \\
\text { patients with ACS. }\end{array}$ & $\begin{array}{l}\text { Should not be given to patients with } \\
\text { acute cardiac ischemia (patients with } \\
\text { ACS). }\end{array}$ \\
\hline
\end{tabular}




\begin{tabular}{|c|c|c|c|}
\hline $\begin{array}{l}\text { Medication } \\
\text { Class/Action(s) }\end{array}$ & Examples/Dose Recommendations & Side Effects & Nursing Implications \\
\hline $\begin{array}{l}\text { Inotropes } \\
\text { Dopamine } \\
\text { Sympathomimetic ( } \uparrow \\
\text { HR and CO). Effects } \\
\text { are dose dependent. } \\
\text { Best choice for "cold } \\
\text { and dry” or those in } \\
\text { cardiogenic shock. }\end{array}$ & $\begin{array}{l}\text { Starting dose: } 2 \mu \mathrm{g} / \mathrm{kg} / \mathrm{min} \text { (no loading dose). } \\
\text { Adjustment increment: } 0.005 \mu \mathrm{g} / \mathrm{kg} / \mathrm{min} \text {; bolus } \\
1 \mu \mathrm{g} / \mathrm{kg} \text { every } 3 \mathrm{~h} \text { to maximum dose of } \\
10 \mu \mathrm{g} / \mathrm{kg} / \mathrm{min} \text {. } \\
\text { Note: } \mathrm{Low} \text { dose }(<3 \mu \mathrm{g} / \mathrm{kg} / \mathrm{min})=\uparrow \text { urine output and } \\
\text { sodium excretion. Moderate dose }(3-5 \mu \mathrm{g} / \mathrm{kg} / \mathrm{min})= \\
\text { inotrope effect }(\uparrow \mathrm{CO} \text { and SBP). High dose } \\
(>5 \mu \mathrm{g} / \mathrm{kg} / \mathrm{min})=\text { vasopressor effect ( } \uparrow \mathrm{CO}, \mathrm{BP} ; \downarrow \\
\text { blood to kidneys and periphery). }\end{array}$ & $\begin{array}{l}\text { Common side effect: } \\
\text { Tachycardia, headache, } \\
\text { nausea, } \downarrow \text { urine output } \\
\text { (with high doses). } \\
\text { Serious side effect: tissue } \\
\text { necrosis. }\end{array}$ & $\begin{array}{l}\text { All should be given via an infusion } \\
\text { pump. All should be started and } \\
\text { stopped gradually (weaned). } \\
\text { Frequent monitoring of BP, HR, and } \\
\text { cardiac rhythm. } \\
\text { Notify medical team if patient } \\
\text { develops symptomatic hypotension } \\
\text { or serious arrhythmia. } \\
\text { Most (not all) complications are } \\
\text { related to higher doses and/or longer } \\
\text { lengths of time on IV inotropes. }\end{array}$ \\
\hline $\begin{array}{l}\text { Dobutamine } \\
\text { Synthetic } \\
\text { catecholamine. } \\
\text { Stimulates } \beta_{1} \text { and } \beta_{2} \\
\text { adrenergic receptors ( } \uparrow \\
\text { HR, BP, and } \\
\text { contractility). Dose } \\
\text { dependent } \uparrow \text { CO and } \downarrow \\
\text { PCWP. }\end{array}$ & $\begin{array}{l}\text { Starting dose: } 2-5 \mu \mathrm{g} / \mathrm{kg} / \mathrm{min} \text { (*no loading dose). } \\
\text { Typical dose range: } 2.5-20 \mu \mathrm{g} / \mathrm{kg} / \mathrm{min} \text { (side effects } \\
\text { are dose dependent). } \\
\text { Adjustment increment: } 2.5-5 \mu \mathrm{g} / \mathrm{kg} / \text { min every } 5- \\
15 \text { min. }\end{array}$ & $\begin{array}{l}\text { Common side effect: } \uparrow \text { or } \\
\downarrow \text { BP, headache, } \\
\text { tachycardia (more likely } \\
\text { with this inotrope), } \\
\text { nausea, fever. } \\
\text { Serious side effect: } \\
\text { hypersensitivity, increased } \\
\text { myocardial ischemia, AF. }\end{array}$ & $\begin{array}{l}\text { Best choice for patients who are } \\
\text { "cold and dry" (SBP }<90 \mathrm{~mm} \text { Hg). } \\
\text { Avoid in patients with ACS (due to } \\
\uparrow \mathrm{HR} \text { and myocardial oxygen } \\
\text { demand). }\end{array}$ \\
\hline $\begin{array}{l}\text { Milrinone } \\
\text { Phodiesterase type-3 } \\
\text { inhibitor. } \uparrow \text { intracellular } \\
\text { calcium concentration, } \\
\text { myocardial } \\
\text { contractility and } \\
\text { myocardial relaxation. } \\
\text { ( } \uparrow \text { arterial and venous } \\
\text { vasodilation, } \downarrow \text { SVR } \\
\text { and PVR, } \uparrow \mathrm{CO} \text { ). }\end{array}$ & $\begin{array}{l}\text { Initial loading dose: } 50 \mu \mathrm{g} / \mathrm{kg} \text { (may omit if a concern } \\
\text { for hypotension). } \\
\text { Starting infusion: } 0.25 \mu \mathrm{g} / \mathrm{kg} / \mathrm{min} \text {. } \\
\text { Typical dose range: } 0.25-0.75 \mu \mathrm{g} / \mathrm{kg} / \mathrm{min} \text {. } \\
\text { Adjustment increment: titration based on } \\
\text { hemodynamic response ( } \uparrow \mathrm{CO} \text { and } \downarrow \mathrm{PCWP} \text { ). }\end{array}$ & $\begin{array}{l}\text { Common side effects: } \\
\text { Tachycardia, hypotension } \\
\text { (more likely with this } \\
\text { inotrope), atrial and } \\
\text { ventricular arrhythmias. } \\
\text { Serious side effects: } \\
\text { Long-term use associated } \\
\text { with decreased survival } \\
\text { (cardiac arrest). }\end{array}$ & $\begin{array}{l}\text { Best choice for patients who are } \\
\text { "cold and wet" (SBP }<90 \mathrm{~mm} \mathrm{Hg} \text { ). } \\
\text { Better choice for patients who are on } \\
\text { beta-blockers (compared to } \\
\text { dobutamine which stimulates beta- } \\
\text { receptors). }\end{array}$ \\
\hline
\end{tabular}

Abbreviations: ACS, acute coronary syndrome; AF, atrial fibrillation; BP, blood pressure; CO, cardiac output; $\mathrm{CrCl}$, creatinine clearance; CVP, central venous pressure; HR, heart rate; IV, intravenous; PCWP, pulmonary capillary wedge pressure; PVR, peripheral vascular resistance; SBP, systolic blood pressure; SVR, systemic vascular resistance; $\uparrow$, increase; $\downarrow$, decrease.

Data from Refs. ${ }^{12,14-16,19}$ 
Table 7. Pharmacologic treatment for patients with ACS

\begin{tabular}{|c|c|c|}
\hline $\begin{array}{l}\text { Medication/Use } \\
\text { in ACS }\end{array}$ & Indication & Nursing Implications \\
\hline $\begin{array}{l}\text { NTG } \\
\text { Anti-ischemic } \\
\text { therapy. }\end{array}$ & $\begin{array}{l}\text { Sublingual NTG } 0.4 \text { mg every } 5 \text { min up to } 3 \text { doses to treat } \\
\text { ongoing ischemic discomfort. } \\
\text { If symptoms continue after } 3 \text { sublingual NTGs, then assess } \\
\text { the need for IV nitroglycerin. } \\
\text { Intravenous NTG to treat persistent ischemia, pulmonary } \\
\text { congestion, or HTN associated with the first } 48 \text { h of the ACS } \\
\text { event. }\end{array}$ & $\begin{array}{l}\text { Monitor for BP/HR for hypotension and tachycardia. } \\
\text { Caution the patient that he or she may experience a headache. } \\
\text { Treat headache with prn pain medications. } \\
\text { Tolerance may develop in patients who have received }>24 \text { h of } \\
\text { continuous IV NTG. For those who require IV NTG beyond } \\
24 \text { h, an increase of dose may be needed to maintain the anti- } \\
\text { ischemic effect. Patients who have been symptom free for } 12- \\
24 \mathrm{~h} \text { after IV NTG may be converted to oral or topical NTG. } \\
\text { Contraindications: SBP }<90 \text { mm Hg or BP } \geq 30 \text { mm Hg lower } \\
\text { than their baseline, severe bradycardia (HR }<50 / \text { min), } \\
\text { tachycardia (HR }>100 / m i n) \text { in the absence of symptomatic HF } \\
\text { or RV infarct. } \\
\text { Should not be given in patients who have received a } \\
\text { phosphodiesterase inhibitor for erectile dysfunction within } 24 \mathrm{~h} \\
\text { of sildenafil or } 48 \text { h of tadalafil use. The time frame for } \\
\text { vardenafil has not been established. }\end{array}$ \\
\hline $\begin{array}{l}\text { Beta-blocker } \\
\text { therapy } \\
\text { Anti-ischemic, } \\
\text { anti-arrhythmic, } \\
\text { mortality } \\
\text { reduction. }\end{array}$ & $\begin{array}{l}\text { Oral beta-blocker therapy should be given within the first } \\
24 \text { h of an ACS event. } \\
\text { IV beta-blockers may be considered for ongoing ischemic } \\
\text { symptoms, especially with concurrent tachycardia or HTN. } \\
\text { Nondihydropyridine calcium channel blockers (verapamil or } \\
\text { diltiazem) may be given if beta-blockers are not tolerated or } \\
\text { are contraindicated (except if severe LV dysfunction or other } \\
\text { contraindications). }\end{array}$ & $\begin{array}{l}\text { Monitor the patient's HR, BP, and heart rhythm. } \\
\text { Lower doses may be needed initially for elders to evaluate the } \\
\text { patient's response (due to the high first-pass effect in the liver } \\
\text { and due to age-related changes to baroreceptors and beta- } \\
\text { adrenergic receptors in the body). } \\
\text { Contraindications: signs of HF, evidence of low output state } \\
\text { (marked hypotension), symptomatic bradycardia, advanced } \\
\text { heart block (2nd-degree or 3rd-degree AV block), active asthma } \\
\text { or reactive airway disease. }\end{array}$ \\
\hline $\begin{array}{l}\text { ACE inhibitor } \\
\text { therapy } \\
\downarrow \text { ventricular } \\
\text { remodeling. } \uparrow \\
\text { long-term } \\
\text { survival. }\end{array}$ & $\begin{array}{l}\text { Oral ACE inhibitor within first } 24 \text { h if the patient has } \\
\text { pulmonary congestion, } L V E F \leq 40 \% \text {. } \\
\text { Substitute: ARB. }\end{array}$ & $\begin{array}{l}\text { Monitor the patient's HR, BP, and heart rhythm. } \\
\text { Watch for hyperkalemia or a decline in kidney function in } \\
\text { elders, especially those with underlying kidney impairment. } \\
\text { Contraindications: SBP }<100 \mathrm{mg} \mathrm{Hg} \text { or BP } \geq 30 \text { mm Hg below } \\
\text { their baseline. }\end{array}$ \\
\hline
\end{tabular}




\begin{tabular}{|c|c|c|}
\hline $\begin{array}{l}\text { Medication/Use } \\
\text { in ACS }\end{array}$ & Indication & Nursing Implications \\
\hline $\begin{array}{l}\text { Antiplatelet } \\
\text { therapy (aspirin, } \\
\text { clopidogrel, } \\
\text { prasugrel, or } \\
\text { tigarelor). }\end{array}$ & $\begin{array}{l}\text { Aspirin } 160-325 \mathrm{mg} \text {, nonenteric coated should be chewed at } \\
\text { the time of presentation and given orally daily thereafter } \\
\text { (100-325 mg). } \\
\text { Substitute: clopidogrel } 75 \text { mg daily (if aspirin allergy). } \\
\text { Dual antiplatelet therapy (aspirin + clopidogrel, prasugrel, or } \\
\text { tigarelor) should be considered for those having an early } \\
\text { invasive approach (cardiac catheterization within } 48 \text { h). }\end{array}$ & $\begin{array}{l}\text { Monitor patients for bleeding. } \\
\text { When using dual antiplatelet therapy, aspirin doses should be } \\
\leq 100 \mathrm{mg} \text { daily due to the increased risk of bleeding. } \\
\text { Prasugrel is contraindicated in patients } \geq 75 \text { y due to } \uparrow \text { risk of } \\
\text { death and intracranial bleeding. }\end{array}$ \\
\hline $\begin{array}{l}\text { Intravenous } \\
\text { glycoprotein } \\
\text { IIb/IIIa } \\
\text { inhibitors }\end{array}$ & $\begin{array}{l}\text { Eptifibatide: Weight-based bolus of } 180 \mu \mathrm{g} / \mathrm{kg} \text { and infusion } \\
\text { of } 2.0 \mu \mathrm{g} / \mathrm{kg} / \mathrm{min} \text {. Infusion should be adjusted if } \mathrm{CrCl} \\
<50 \mathrm{~mL} / \mathrm{min} \text { to } 1.0 \mu \mathrm{g} / \mathrm{kg} / \mathrm{min} \text {. } \\
\text { Tirofiban: Weight-based bolus of } 12 \mu \mathrm{g} / \mathrm{kg} \text { and infusion of } \\
0.1 \mu \mathrm{g} / \mathrm{kg} / \mathrm{min} \text {. Should be adjusted for kidney function ( } \mathrm{CrCl} \\
<30 \mathrm{~mL} / \mathrm{min} \text { ) to bolus of } 6 \mu \mathrm{g} / \mathrm{kg} \text { and infusion of } \\
0.05 \mu \mathrm{g} / \mathrm{kg} / \mathrm{min} \text {. }\end{array}$ & $\begin{array}{l}\text { Calculate the patient's } \mathrm{CrCl} \text { each day to verify that the patient is } \\
\text { on the proper dose. } \\
\text { Monitor the patient for bleeding. } \\
\text { Increased bleeding is seen with elderly patients, especially if not } \\
\text { properly weight adjusted or dose adjusted based on CrCl. } \\
\text { Bleeding risk also increases with the number of antithrombin } \\
\text { and antiplatelet agents given concurrently. }\end{array}$ \\
\hline $\begin{array}{l}\text { Antithrombin } \\
\text { therapy } \\
\text { (heparin) }\end{array}$ & $\begin{array}{l}\text { Unfractionated heparin: weight-based bolus of } 60 \mu \mathrm{g} / \mathrm{kg} \text { and } \\
\text { infusion of } 12 \mu \mathrm{g} / \mathrm{kg} / \mathrm{min} \text {. Maximum bolus } 4000 \mathrm{units} \text { and } \\
\text { infusion of } 900 \mathrm{u} / \mathrm{h} \text { or } 5000 \text {-unit bolus and infusion of } 1000 \\
\mathrm{u} / \mathrm{h} \text { if patient weighs }>100 \mathrm{~kg} \text {. } \\
\text { LMWH: weight-based dose of } 1 \mathrm{mg} / \mathrm{kg} \text { every } 12 \mathrm{~h} \text {. } \\
\text { Adjustment in infusion for kidney function. If CrCl } \\
<30 \mathrm{~mL} / \mathrm{min} \text {, then } 1 \mathrm{mg} / \mathrm{kg} \text { subcutaneously every } 24 \mathrm{~h} \text {. }\end{array}$ & $\begin{array}{l}\text { Monitor the patient for bleeding. Every elderly patient should } \\
\text { have CrCl calculated every day. } \\
\text { Patients are at } \uparrow \text { risk for bleeding if altered kidney function. } \\
\text { Alterations in body composition and protein levels in elders } \\
\text { may result in overestimation of heparin dosing. }\end{array}$ \\
\hline
\end{tabular}

Abbreviations: ACE, angiotensin-converting enzyme; ACS, acute coronary syndrome; ARB, angiotensin receptor blocker; AV, atrioventricular; BP, blood pressure; CO, cardiac output; $\mathrm{CrCl}$, creatinine clearance; CVP, central venous pressure; HR, heart rate; IV, intravenous; LMWH, low molecular weight heparin; LVEF, left ventricular ejection fraction; NTG, nitroglycerin; prn, as needed; RV, right ventricular; SBP, systolic blood pressure; $\mathrm{u} / \mathrm{h}$, units per hour; $\uparrow$, increase; $\downarrow$, decrease.

Data from Refs. ${ }^{24-26}$ 